\title{
Radoslav Tomić
}

Institut za povijest umjetnosti, Zagreb

\section{Giovanni Maria Morlaiter u Dalmaciji}

\author{
Izvorni znanstveni rad - Original scientific paper \\ Predan - Received 26. 6. 2017. \\ UDK 73.034.7(497.58) \\ 7Morlaiter, Giovanni Maria
}

\begin{abstract}
Sažetak
Autor analizira dalmatinski opus kipara Giovannija Marije Morlaitera (Venecija, 1699.-1781.). Utvrduje se da je umjetnik na hrvatskoj obali zastupljen djelima koja su nastala od mladenačkih godina do starosti. Najranija su djela iz 1729./1730. godine u crkvi sv. Ignacija u Dubrovniku. Riječ je o kipovima Djevičanstva i Poniznosti na oltaru Prikazanja Marije u hramu te Vjere i Ljubavi na oltaru sv. Augustina. Naručitelj je bio Dubrovčanin Franjo Rogačić (Rogacci). Potom, 1746. godine Morlaiter kleše u kamenu tri andela na oltaru Gospe od Ružarija u župnoj crkvi Rođenja Blažene Djevice Marije na Prčanju u Boki kotorskoj. Sredinom stoljeća dobiva narudžbu da za splitsku katedralu izradi oltar sv. Dujma. To je najambiciozniji Morlaiterov rad za dalmatinske naručitelje, a dovršen je 1767. godine. Kako je
\end{abstract}

Ključne riječi: Dalmacija, kiparstvo, 18. stoljeće, Giovanni Maria Morlaiter, Gregorio Morlaiter zabilježio Julije Bajamonti, naručitelji su u Rimu nabavili najvrsniji uzorak prema kojemu je Morlaiter trebao izraditi splitski oltar. U to je vrijeme, izmedu 1759. i 1762. godine, zajedno soltaristom Lorenzom Bonom podigao tabernakul oltara s mramornim kipovima andela $u$ benediktinskoj crkvi sv. Marije u Zadru. U istom je gradu 1764. godine izradio grobnicu vojnom inženjeru Giovanniju Francescu Rossiniju s portretnim poprsjem, kipom sv. Šimuna i andelima. Za oba zadarska djela sačuvani su terakotni modeli u Ca'Rezzonico u Veneciji. Za glavni oltar u crkvi sv. Marije dokumenti spominju i crtež, dok opsežna arhivska građa o njegovoj izradi uključuje i vlastoručno pismo što ga je kipar uputio benediktinskim redovnicama u Zadar.
Djelatnost kipara Giovannija Marije Morlaitera (Venecija, 1699.-1781.) za naručitelje iz Dalmacije sve donedavno nije bila cjelovito istražena. Pisalo se najčešće o oltaru sv. Dujma u splitskoj katedrali za koji je 1770. godine Julije Bajamonti zabilježio da je djelo toga mletačkog kipara. ${ }^{1}$ Iako je 1806. godine Giannantonio Moschini naveo da je Morlaiter radio neka djela za Dubrovačku Republiku, ${ }^{2}$ a Ivan Kukuljević Sakcinski to isto ponovio 1859 . godine ${ }^{3}$ tek su novija istraživanja identificirala njegova četiri kipa u isusovačkoj crkvi sv. Ignacija u Dubrovniku. ${ }^{4} \mathrm{Za}$ oltar Prikazanja Marije u hramu izradio je kipove Djevičanstva i Poniznosti, a za oltar Sv. Augustina kipove Vjere i Ljubavi. Mramorni oltar sv. Augustina naručio je u Veneciji Franjo Rogačić (Francesco Rogacci) iz Dubrovnika 1729. godine, a 16. srpnja 1730. godine istovjetni oltar Marijina prikazanja u hramu, koji su postavljeni sučelice u prve kapele do ulaza, na sjevernoj i južnoj strani isusovačke crkve sv. Ignacija. ${ }^{5} \mathrm{Na}$ njima su kartuše s natpisima. Na oltaru sv. Augustina zapisano je: $S U$ PER ABUNDAVIT GRATIA CUM FIDE ET DILECTIONE, a na oltaru Marijina prikazanja: VIRGINITATE PLACUIT, HUMILITATE CONCEPIT. Na oltarima su pale Prikazanja
Bogorodice u hramu i Sv. Augustin koje je izradio Bartolomeo Litterini. ${ }^{6}$ Oltari su nastali prema modelima Andree i Giuseppea Pozza. ${ }^{7}$ Kipovi su postavljeni na ugaone obrate predele sa strane visokog retabla i djeluju maleno u odnosu na oltarnu cjelinu. Na njihovim su bazama pričvršćeni grbovi naručitelja Rogačića, što znači da je Franjo Rogačić stajao iza ukupne opreme koja uključuje oltare, kipove i pale.

Riječ je o ranim Morlaiterovim djelima i o prvoj narudžbi kod toga umjetnika od dalmatinskih naručitelja. Odlikuje ih izbalansirani pokret tijela u blagom kontrapostu, sitne glave $\mathrm{s}$ arhaizirajućim osmijehom koji diskretno lebdi na oblim licima, virtuozno nabrana draperija i metalno oštro omeđen obris njihovih elegantnih tijela. Kip Vjere s Rogačićeva oltara ima preko glave prebačen veo koji pada do očiju. Morlaiter je taj motiv koristio na ranim i kasnim djelima, u Veneciji (usp. Bogorodicu na kipu Pietà, Sant'Eufemia, Giudecca) i u Splitu (usp. kip Vjere na oltaru sv. Dujma). Mladenački kip u Dubrovniku, izdužena, vretanasta i zarotirana tijela, sitnih, kaligrafskih nabora odjeće postao je u kasnijim redakcijama tromiji, zbijeniji, a draperija gušća iako se kiparova sklonost prema oštrom, preciznom i kontroliranom nabiranju 


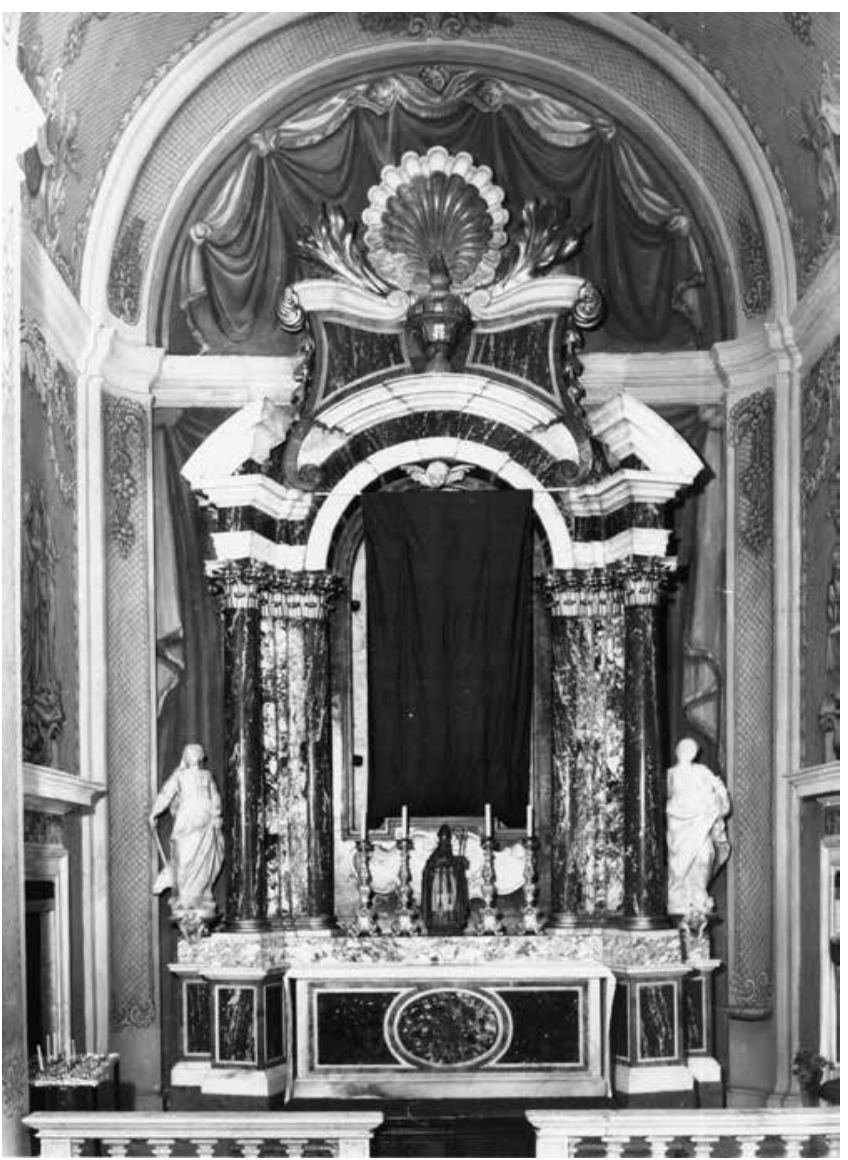

Oltar Marijina prikazanja u hramu, Dubrovnik, crkva sv. Ignacija Altar of Mary's presentation in the Temple, Dubrovnik, St Ignatius church

zadržala i u kasnom razdoblju, pa i onda kada je, pritisnut godinama i brojnim narudžbama, dio posla prepuštao suradnicima u radionici.

Za tri kamena kipa anđela u župnoj crkvi Rođenja Marijina u Prčanju u Boki kotorskoj naručena 1746. godine sačuvana je u tamošnjem župnom arhivu priznanica koju je Morlaiter vlastoručno potpisao potvrđujući isplatu. Mramorni oltar na kojemu su tri anđela prenesen je 1917. godine iz stare župne crkve u novu sagrađenu prema projektu Bernardina Macaruzzija. ${ }^{8}$ Riječ je o dvama anđelima koji sjede na stranicama prekinutog zabata, dok središnji stoji na profiliranom postamentu. Na tim djelima iz zrelih godina svoga stvaralaštva kipar je najveći uspjeh postigao u obradi draperije koja prekriva debeljuškasta tijela i treperi na svjetlu. Moglo bi se reći da je upravo virtuozno nabirao meku tkaninu ispod koje se ocrtavaju obrisi i mekoća tijela. Tako spontan, neposredan, prirodan i neusiljen ritam valovitih nabora na tkanini bez oštih rezova i trokutnih završetaka uvjetovan je vjerojatno i činjenicom da su kipovi izrađeni u kamenu, a ne u mramoru. ${ }^{9}$ Iz iste godine datiraju i dva anđela isklesana u mramoru za župnu crkvu u gradiću Belvedere d'Aquileia (Udine), pa nije čudno da je njihova neposredna bliskost očita i izrazita. Ako pažljivije pogledamo prčanjske anđele,

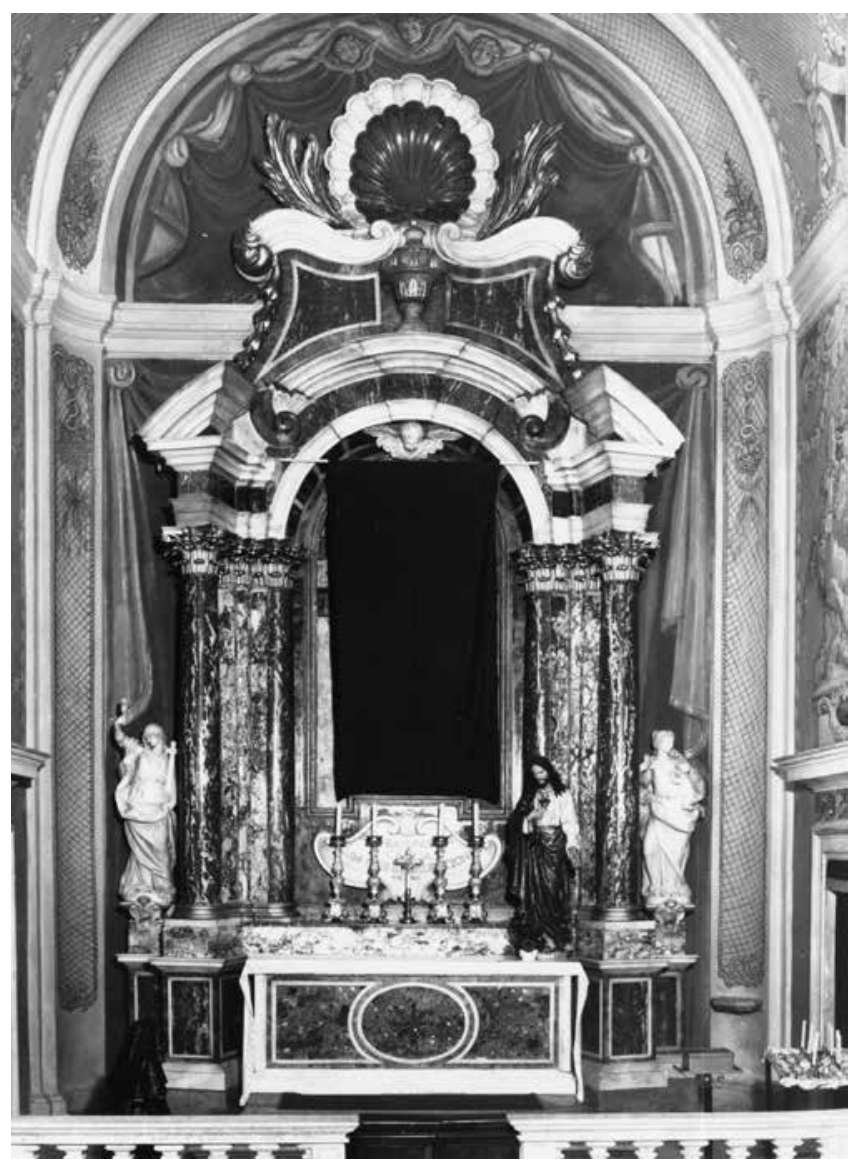

Oltar sv. Augustina, Dubrovnik, crkva sv. Ignacija Altar of St Augustine, Dubrovnik, St Ignatius' church

moglo bi se reći da su oni 'uvertira' u alegorijske kipove na splitskom oltaru sv. Dujma. Prema novijim istraživanjima o njegovu podizanju razmišljalo se već od 1739 . godine. U tu je svrhu bio angažiran i svestrani Mihovil Luposignoli koji je "projektirao veličanstveni oltar s rakom u koju bi se stavile moći našeg sveca $\ll{ }^{10}$ No njegov projekt nije izveden, pa je nakon Luposignolijeve smrti 1750. godine trebalo započeti ispočetka. Radi toga je, prema pisanju Julija Bajamontija, "nabavljen od najvrsnijih profesora koji postojahu u Rimu odgovarajući uzorak i taj je poslan u Veneciju gosp. Morlaiteru, izvrsnome kiparu, koji se svojski prihvatio posla «. ${ }^{11}$ Nije poznato kada je sklopljen ugovor s Morlaiterom, ali on na oltaru radi već $1757 .{ }^{12}$ a završava ga tek 1767 . godine. $U$ oblikovanju oltara G. M. Morlaiter je, kako su zabilježili lokalni kroničari, prema izravnoj želji naručitelja, slijedio neki rimski predložak. Oltar je složen od dva dijela, pravokutnog stipesa i trokutno koncipiranoga gornjeg dijela sa sarkofagom, alegorijskim i anđeoskim figurama. Na predoltarniku je u plitkom reljefu prikazana Smrt sv. Dujma pred rimskim namjesnikom Maurilijem u Saloni: svetac u biskupskoj odjeći kleknuo je na zemlju i prignute glave očekuje udarac mača koji će krvnik spustiti na njegov vrat, dok ga drugi drži za ruke. Ispred sveca, na zemlji je mitra, znak njegove biskupske časti. Na desnoj strani sjedi rimski namjesnik i promatra 

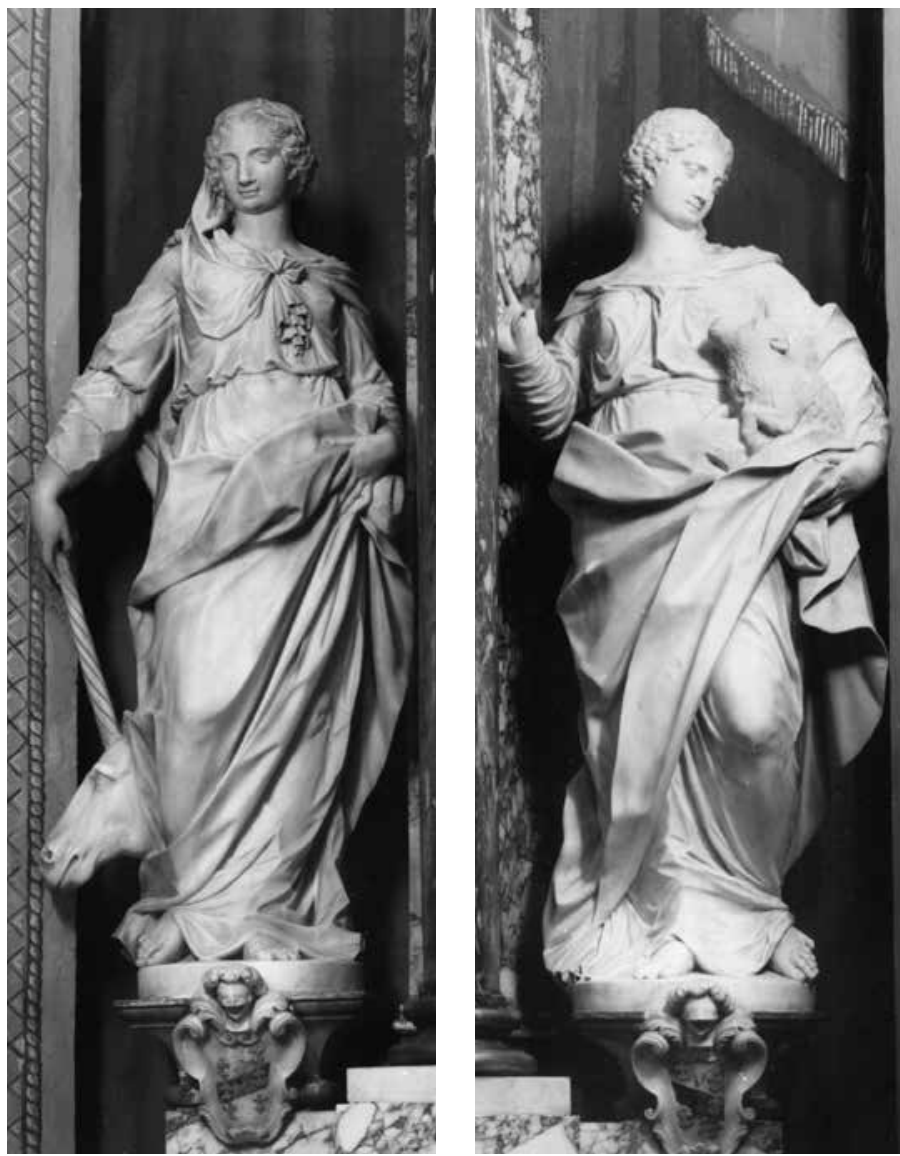

G. M. Morlaiter, Djevičanstvo i Poniznost, oltar Marijina prikazanja u hramu, Dubrovnik, crkva sv. Ignacija

G. M. Morlaiter, Virginity and Humility, altar of Mary's presentation in the Temple, Dubrovnik, St Ignatius' church

prizor mučenja, a s lijeve je vojnik sa štitom, kacigom i dugim štapom dok u pozadini, iza namjesnika Maurilija, svećenik drži kip Jupitera sa svežnjem munja u ruci. Njemu je Dujam uskratio žrtvu i to ga je stajalo života. Prizor se odvija na terasi sa stupovima ispred otvorenog krajolika.

Isticala se ljepota reljefa i naglašavala voštana mekoća prikaza u mramoru: slikovite figure glatke, svjetlucave puti i tkanine koje se prelijevaju na svjetlu stvarajući iluziju različite tvarnosti, od sjaja svile i gustoće brokata biskupove odjeće do metalnog svjetlucanja kacige i štita na vojniku i kamenita krajolika s vegetacijom koja treperi u blagom ritmu. Površina ugaonih pilastara predoltarnika ispunjena je reljefno oblikovanim cvjetnim vijencem..

Na menzi je plitko i široko postolje ukrašeno gusto oblikovanim festonima na kojemu sjede dvije snažne ženske figure koje prikazuju kreposti (vrline) Jakost i Vjeru. Jakost je prikazana kao žena u vojničkoj odjeći, sa šljemom i velikom perjanicom, dok je Vjera u dugoj haljini s velom preko glave i kaležom s hostijom u rukama. Između njih na postolju s ugaonim volutama je sarkofag izvijene linije izrađen u raznobojnom mramoru. S prednje strane sarkofag zatvaraju srebrne vratnice ukrašene cvijećem, volutama i anđeoskim glavicama. U središnjoj je kartuši natpis:
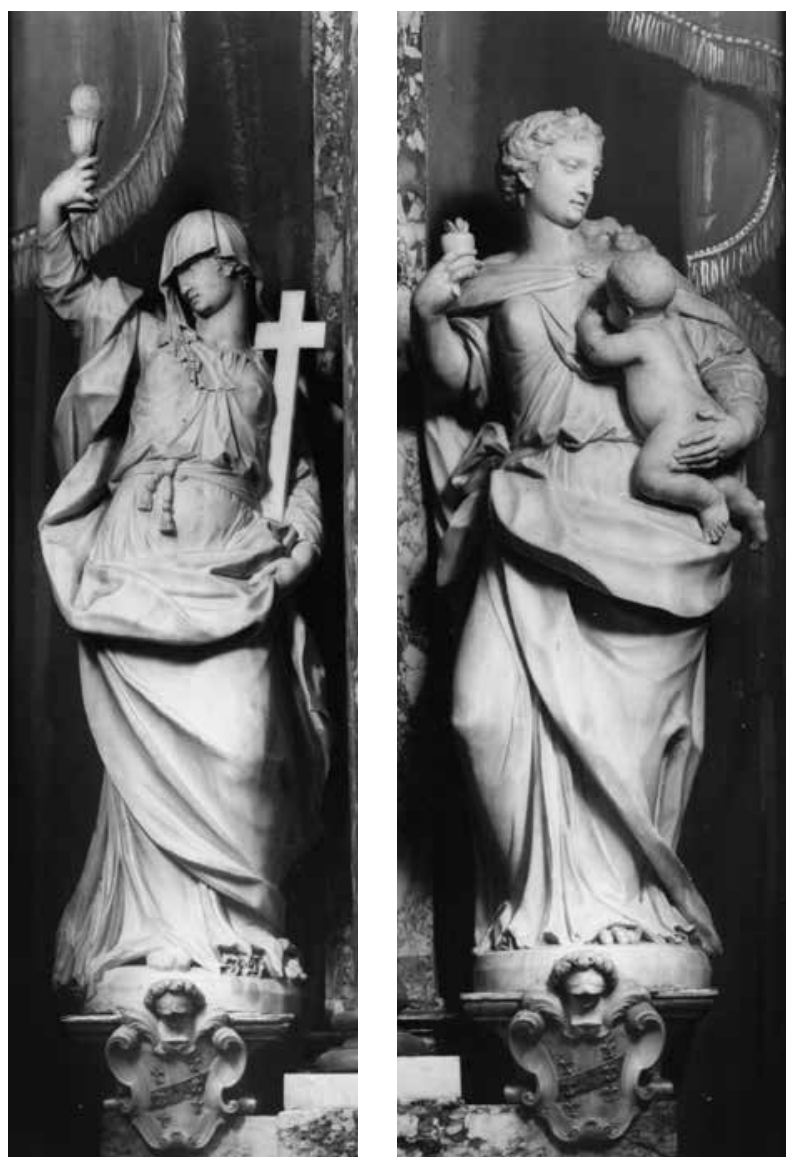

G. M. Morlaiter, Vjera i Milosrde, oltar sv. Augustina, Dubrovnik, crkva sv. Ignacija

G. M. Morlaiter, Faith and Charity, altar of St Augustine, Dubrovnik, St Ignatius' church

\section{S. DOMNIUS M (ARTYR) \\ P(RI)MUS SALON(ITANUS) PONT(IFEX) \\ AP(OSTO)LORUM P(RI)N(CI)PIS \\ DISCIPULUS \\ HIC IACET}

(Ovjde leži sv. Dujam mučenik, prvi solinski biskup, učenik prvaka apostolā $).{ }^{13}$

Ispod sarkofaga su u bijelom mramoru reljefno prikazani pladanj na kojemu se nalazi kalež, mitra i štola, a iznad toga na višebojnom mramoru Kristov monogram. Na poklopcu sarkofaga dvije su glavice kerubina i palmine grane »objedinjene krunom od pozlaćene kovine«, a u vrhu dva krilata, bucmasta anđela drže pastoral i nadbiskupski križ (crux gemina), »također od pozlaćene kovine« ${ }^{14}$

Ikonografija splitskog žrtvenika temelji se na učenju lokalne crkve da je sv. Dujam učenik sv. Petra i osnivač biskupije u Saloni u kojoj je podnio mučeničku smrt. Splitska nadbiskupija nasljednica je salonitanske, stoga je Dujam, apostolski učenik, biskup i mučenik, čije su svete moći prenijete iz Salone (Solina) u Split, u katedralu i čuvaju se upravo u sarkofagu na oltaru što ga je izradio Giovanni Maria Morlaiter. Salonitanski temelji splitske nadbiskupije i njezin svetac, 


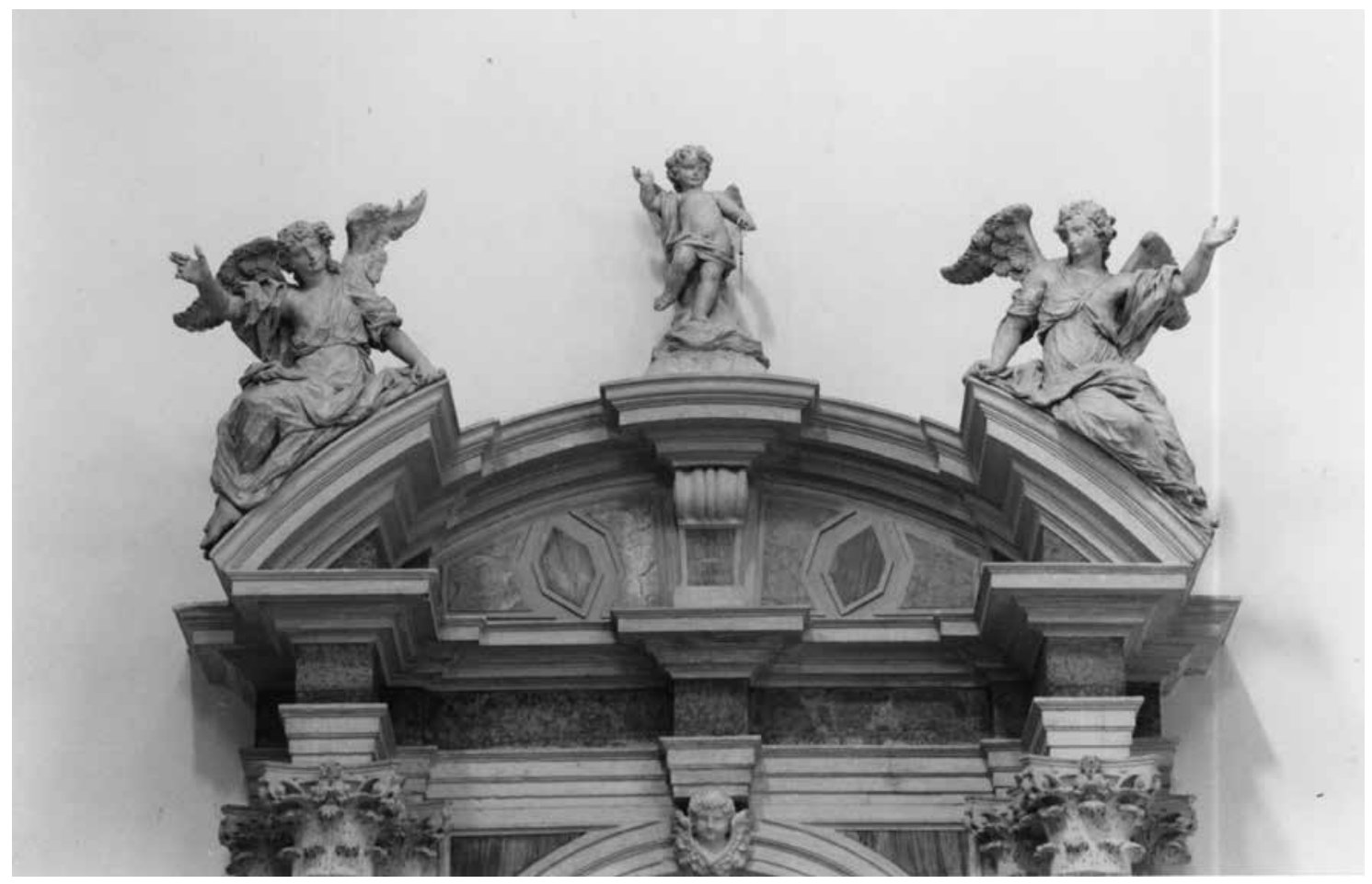

G. M. Morlaiter, anđeli, oltar Gospe od Ružarija, Prčanj, župna crkva Rođenja Blažene Djevice Marije G. M. Morlaiter, Angels, altar of Our Lady of the Holy Rosary, Prčanj, parish church of the Nativity of the Blessed Virgin Mary

apostolski učenik sv. Dujam, osiguravali su splitskoj crkvi povlašten položaj u Dalmaciji, jer takav legitimitet i takvu starinu druge crkvene zajednice i biskupije od Kotora do Zadra nisu imale. Oltar objašnjava i tumači smisao Dujmove žrtve: od mučeničke smrti koju je podnio za kršćanstvo, a prikazana je u reljefu na predoltarniku, njegova se sudbina transformira. Postojanom i jakom vjerom on je od mučenika koji je žrtvovao vlastiti život postao svetac na čijem se uzoru stoljećima gradila nadbiskupska, metropolitanska crkvena zajednica u Splitu. Na menzi stoga i sjede alegorijske figure Vjere i Jakosti koje nose urnu sa svečevim relikvijama dok su u podnožju i na poklopcu simboli Dujmove nadbiskupske časti. Njegovu mučeničku smrt i žrtvu koju je podnio za kršćanski nauk potvrđuju savijene palmine grane između glavica anđela na vrhu sarkofaga.

Oltar sv. Dujma tumači povijest splitske nadbiskupije, objašnjava njezine temelje i metropolitanski položaj koji traje neprekinuto od učenika sv. Petra, salonitanskoga biskupa i mučenika kojemu su splitski nadbiskupi legitimni nasljednici. Takvu predodžbu o nadbiskupu dopunjuju i četiri natpisa u ovalnim posrebrenim okvirima na zidovima svečeve kapele. Natpisi glase: AVE LVMEN DALMATIAE FIRMA SPES SPALATI, potom: AVE SANCTE DISCIPVLE APOSTOLORVM PRINCIPIS, slijedi: PRO LEGE DEI SVI CERTAVIT VSQVE AD MORTEM, te: DEDIT ILLI DOMINVS SACERDOTIVM GENTIS. Na okvirima s natpisom Ave lvmen (...) i Ave sancte (...) urezan je grb splitske plemićke obitelji Cindro. ${ }^{15}$ I okviri »neobaroknog dekorativnog repertoara« i natpisi u njima mogu se datirati u 19. stoljeće što ukazuje da je svijest o svetom zaštitniku i tada bila snažno prisutna.

Mogući rimski predložak za splitski oltar nije se konkretnije istraživao. Ostaje otvoreno što su naručitelji zapravo htjeli i kakav su predložak nudili. Je li bila riječ o konkretnom modelu, o sugestiji, skici ili o verbalnoj eksplikaciji? Alegorijske figure koje pridržavaju urnu s moćima svetaca postale su 'opće' mjesto u baroknoj oltaristici kasnog 17. i 18. stoljeća, ali i na nadgrobnim spomenicima i grobnicama papa, kardinala i uglednih ličnosti. Takav tip oltara udomaćio se, posredstvom mletačkih majstora, i u dalmatinskoj sredini, od Zadra do Kotora. No na oltaru sv. Duje bočno postavljene, živo pokrenute alegorijske figure nisu slobodnostojeće, nego su integrirane i objedinjene u skulptorski oblikovanu cjelinu.

Ako se pokušava ući u trag mogućemu rimskom predlošku, možda put vodi do G. L. Berninija i njegove grobnice pape Urbana VIII. (1628.-1647.) u crkvi sv. Petra u Rimu na kojoj alegorijske figure Ljubavi i Pravde stoje uz urnu, na kojoj papa sjedi i blagosivlje. Monumentalna papina grobnica sigurno je bila poznata »vrsnim profesorima u Rimu« o kojima je pisao Julije Bajamonti, iako se teško može pretpostaviti tko su te osobe koje su, navodno, predložile oblik oltara. Ne smije se smetnuti s uma moguće posredništvo svećenika podrijetlom iz splitske nadbiskupije koji su u to vrijeme živjeli u Rimu, u prvom redu u Zavodu sv. Jerolima.

U vatikanskoj crkvi podignuto je nakon toga još nekoliko papinskih grobnica koje se tipološki nastavljaju na Berninijevo remek-djelo. Među njima je i Berninijeva grobnica pape 


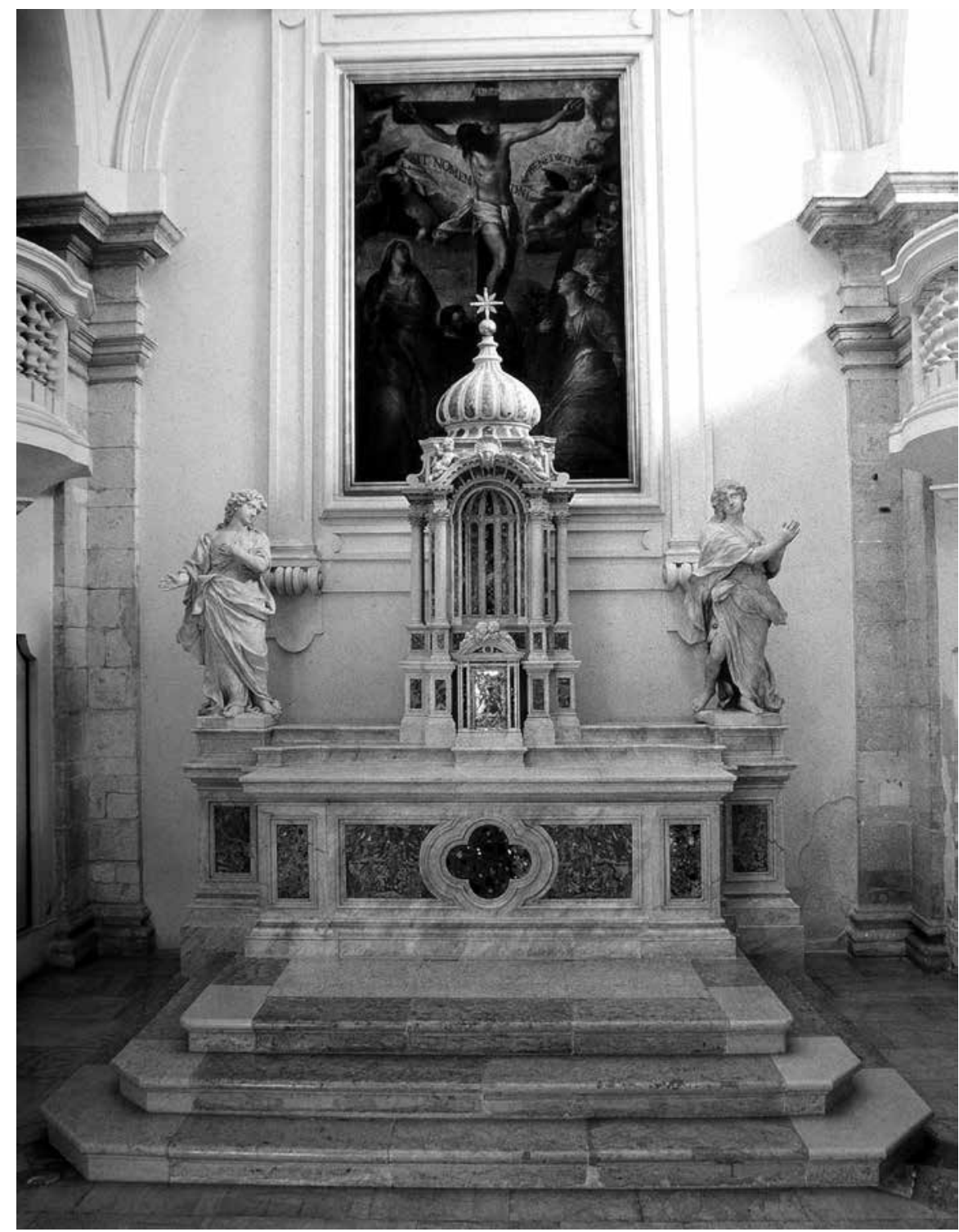

L. Bon i G. M. Morlaiter, glavni oltar, crkva sv. Marije, Zadar

L. Bon and G. M. Morlaiter, main altar, St Mary's church, Zadar

Alessandra VII. (1671.-1678.), grobnica pape Leona XI. koju je 1634./1644. podigao Alessandro Algardi, a slijedila je oblik grobnice Urbana VIII. Piramidalnu kompoziciju oblikuju tri figure: alegorijski likovi sa strane grobnog sarkofaga i papin lik na njegovu poklopcu. No Algardi na pročelju rake kleše reljef s narativnom scenom što svakako ima izvor u rimskim sarkofazima. Takav tip papinske grobnice ponovit će Ercole Ferrata i Giuseppe Mazzuoli na grobnici pape Clementa X. (1682.-1685.), Pierre-Ėtienne Monnot na spomeniku papi Innocentu XI. (1697.-1704.), Camillo Rusconi na grobnici pape Grgura XIII. (1719.-1725.) i Filippo della Valle na grobnici pape Innocenta XII. (1746.), uvijek u crkvi sv. Petra, dok je Pietro Bracci sa suradnicima grobnicu pape Benedikta XIII. podigao 1734. godine u crkvi Santa Maria Sopra Minerva. To svjedoči o difuziji Berninijeva prototipa izvan vatikanske bazilike u druge rimske crkve. ${ }^{16}$
Posebno je zanimljiv Berninijev crtež za grobnicu Matilde di Canossa (Musée des Beaux-Arts, Bruxelles) s kojim splitski oltar pokazuje sličnosti ne samo u trokutnoj kompoziciji nego u rasporedu njegovih dijelova, reljefa, alegorijskih kipova i dekorativnih detalja. ${ }^{17}$

Ukazivanje na Berninijeva djela nije odgovor na pitanje o stvarnom i mogućem rimskom predlošku prema kojemu je nastao splitski oltar sv. Dujma. Ne treba zbunjivati činjenica da su navedeni isključivo grobni spomenici, a ne oltari, jer je žrtvenik u splitskoj katedrali i jedno i drugo. U urni su pohranjeni zemni ostaci biskupa koji se u lokalnoj zajednici štuje kao svetac. Doduše, na oltaru nije oblikovana svečeva figura, jer o njegovu izgledu ne postoje nikakvi uvjerljivi podaci, ali je na predoltarniku prikazana njegova mučenička smrt u reljefu. Rimska rješenja mogla su naručiteljima biti izazov i poticaj, ali je moguće sugestije kipar Giovanni Maria 

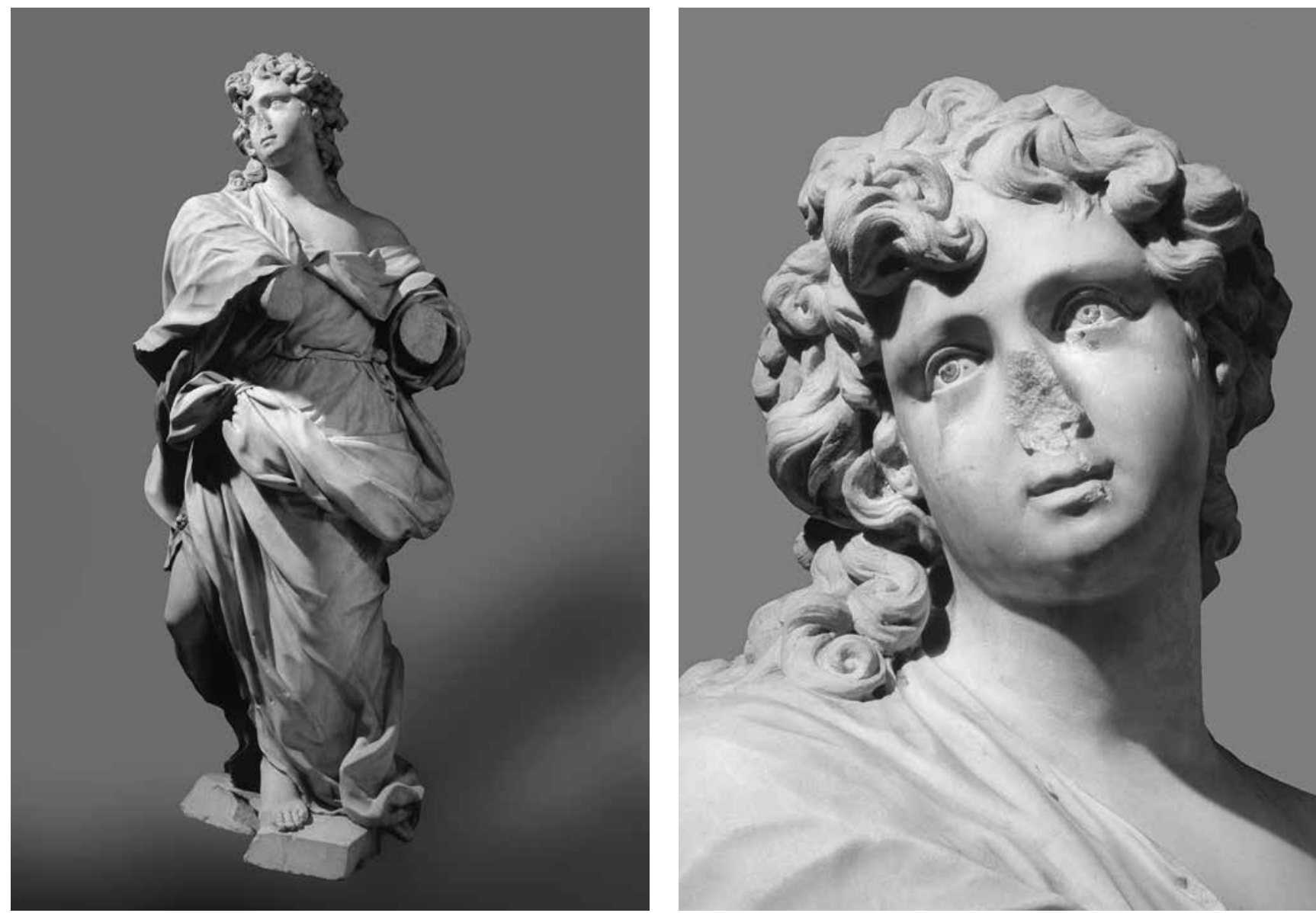

G. M. Morlaiter, Anđeo, glavni oltar u crkvi sv. Marije u Zadru, total i detalj

G. M. Morlaiter, Angel, main altar at St Mary's church in Zadar, full figure and detail

Morlaiter riješio u sklopu vlastite poetike iako skulpturalno oblikovan oltar, kao što je žrtvenik sv. Dujma u Splitu, nema bliskih usporedbi u mletačkoj oltarističkoj praksi 18. stoljeća. Kad se na 'mletačkim' oltarima nalaze alegorijske, anđeoske i svetačke figure, one su u principu slobodnostojeće, osamostaljene figure dok su u Splitu neraskidivo integrirane u oltarnu cjelinu. Njihova su tijela zbijena i obla, a draperija izbrazdana gustim naborima čime se snažno poništava plošnost i naglašava volumen likova i oltarne cjeline. Na taj način postignut je dubinski efekt: postavljen u kapelu, mramorni oltar porculanski čistim i jedrim figurama naglašene tjelesnosti u zamahu predstavlja se u prvom redu kao kompaktna skulptorska cjelina. Splitski žrtvenik nedvojbeno je najsloženije i najljepše djelo koje je Morlaiter izradio za dalmatinske naručitelje.

Oltar sv. Dujma istovremeno je moćnik i nadgrobni spomenik kojemu je u središtu urna sa svečevim relikvijama. U evoluciji toga tipa spomenika iznimno je zanimljiv zavjetni oltar sv. Ivana Nepomuka u katedrali sv. Vida u Pragu. Njega su prema crtežu Johanna Bernarda Fischera von Erlacha izradili između 1733. i 1736. godine mletački kipar Antonio Corradini i bečki zlatar Johann Joseph Würth. Oltar uključuje anđele koji kleče i nose urnu sa svečevim relikvijama i kipom sveca na njezinu poklopcu. ${ }^{18}$ Takav je na dalmatinskoj obali, primjerice, oltar-grobnica sv. Šimuna u Zadru proizišao iz radionice Baldassarea Longhene s kamenim i brončanim kipovima Francesca Cavriolija, ${ }^{19}$ kao i moćnik sv. Tripuna u katedrali u Kotoru što ga je između 1704. i 1708. podigao venecijanski kipar Francesco Cabianca, jer na njima anđeli nose škrinju (urnu) sa svečevim relikvijama. U Kotoru na urni kleči sv. Tripun čime je oltar tipološki i ikonografski postao zaokružen, ali za razliku od splitskog oltara na njemu još uvijek nije ostvarena integracija svih elemenata u nedjeljivu cjelinu. ${ }^{20}$

Tragajući za izvorima Morlaiterova rukopisa, neosporan je i očigledan utjecaj njegova učitelja Alvisea Tagliapietre. No njegovu monumentalnu i herojsku skulpturu snažnih i odlučnih gesti Morlaiter je stišao, preoblikovao u sitnije kipove napetih i nemirnih kretnji iz kojih struji finoća i pulsira život. Pisalo se, opravdano, o njegovoj bliskosti s onodobnim slikarstvom u Veneciji. Iako je bio suvremenik G. B. Tiepolu, teško je reći da između njih postoji prepoznatljiva bliskost. Uputnije je ukazati na Morlaiterovo prijateljstvo sa Sebastianom Riccijem: u nekim njihovim djelima, Riccijevim slikama i Morlaiterovim reljefima (Krist podučava u hramu, Odmor na putu za Egipat, Krštenje Krista) scena je na sličan način organizirana. Napeta krivulja Morlaiterovih gipkih tijela, mesnatih lica, oblih i glatkih udova i prstiju, upalih očiju i blaga osmijeha na kipovima i reljefima mogu se usporediti i 

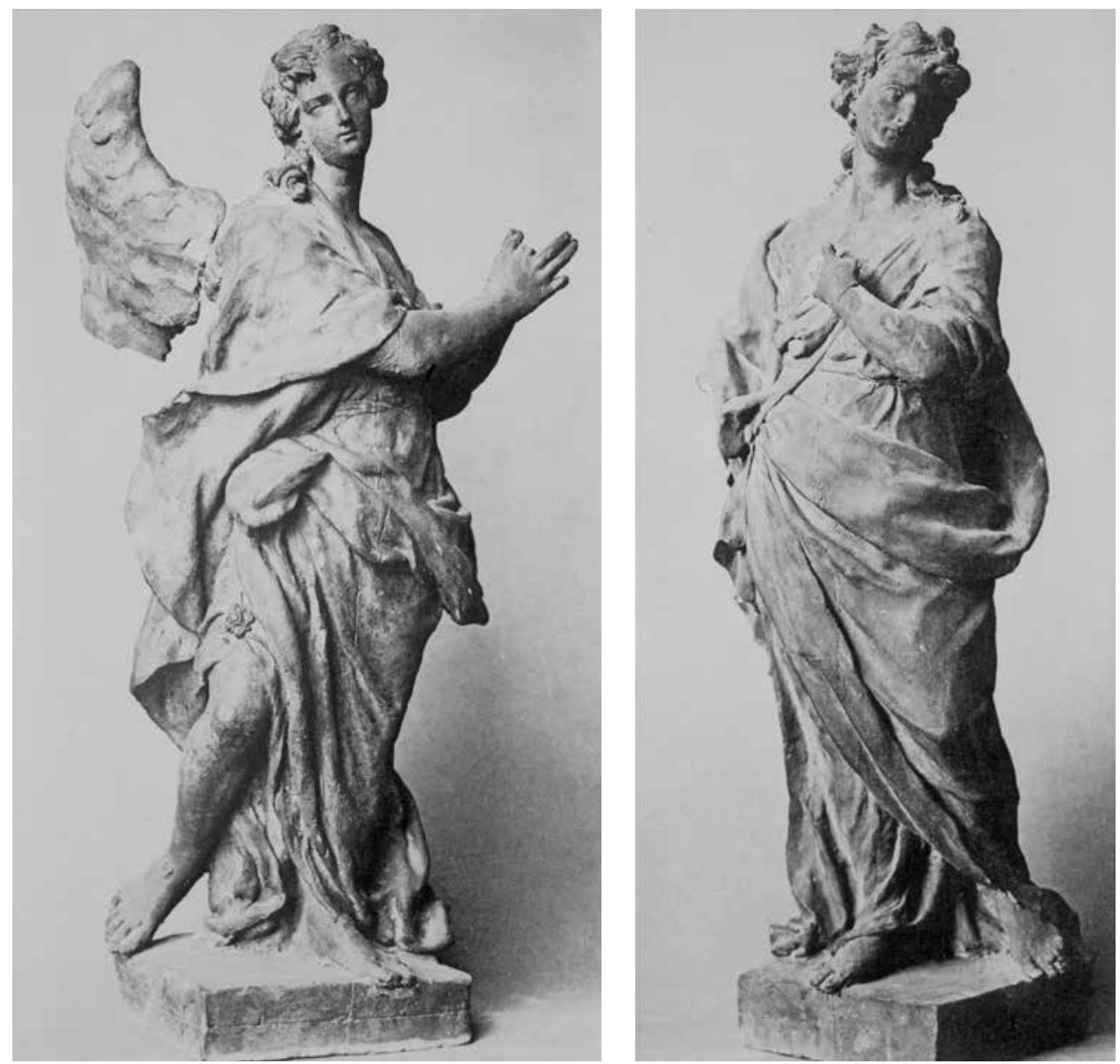

G. M. Morlaiter, Modeli za anđele na glavnom oltaru u crkvi sv. Marije u Zadru, Ca' Rezzonico, Venecija G. M. Morlaiter, Models for angels at the main altar of St Mary's church in Zadar, Ca'Rezzonico, Venice

sa slikarstvom G. B. Pittonija. Taj slikarski karakter njegovih djela, u prvom redu reljefa koje je često radio, davno je prepoznao Giulio Lorenzetti okrstivši ga kao un Pittoni scultore koji je sposoban natjecati se u svojim brojnim bozzettima s mrljastim slikarstvom di un Guardi figurista. ${ }^{21}$

Kada je Kukuljević pisao o glavnom oltaru u benediktinskoj crkvi sv. Marije u Zadru, koristio je dokumente u posjedu obitelji Fanfogna u Zadru. S obzirom na to da je obiteljski arhiv prenijet $\mathrm{u}$ Trogir nakon vjenčanja Antuna Fanfogne s Katarinom Garagnin, onaj dio građe koji se odnosi na Zadar i njegovu prošlost (što se nakon Drugoga svjetskog rata čuva u Državnom arhivu u Splitu) nije bio predmetom stručne i znanstvene obrade. Ostali su stoga nepoznati brojni dokumenti od kojih su neki važni za kupnju i nabavu umjetnina u Zadru i u njegovoj okolici. Tako je izvan dometa istraživača ostala iscrpna dokumentacija i o podizanju glavnog oltara u crkvi sv. Marije, upravo ona koju je vidio i koristio Ivan Kukuljević Sakcinski. Na temelju Kukuljevićeve bilješke i stilske analize identificirao sam 1991. Morlaiterove kipove anđela oštećene u bombardiranjima Zadra tijekom Drugoga svjetskog rata, te 2008. publicirao ulomke pisma što ga je kipar 18. svibnja 1762. godine uputio benediktinkama u Zadar. Prepoznao sam i modele-predloške anđela izrađene u terakoti koji se čuvaju u Museo del Settecento Veneziano di Ca’ Rezzonico u Veneciji. ${ }^{22}$
Publiciranje dokumenta iz Arhiva Garagnin-Fanfogna u Državnom arhivu u Splitu, koji se odnose na glavni oltar u crkvi sv. Marije u Zadru, pruža cjelovitiji uvid o tijeku njegova podizanja od 1759. do 1762 . godine, o majstorima i predstavnicima samostana koji su sklapali ugovor i skrbili o njegovoj izvedbi. Osim Giovannija Marije Morlaitera, u dokumentima se spominje i oltarist Lorenzo Bon koji je bio zadužen za arhitekturu oltara. Treba istaknuti da se spominje i crtež žrtvenika koji do sada nije identificiran, a mogao bi se tumačiti kao crtež na temelju kojeg je sklopljen ugovor (contract drawing). Kad se tome pridodaju bojani modeli od terakote i brojni dokumenti koji uključuju i vlastoručno pismo što ga je kipar uputio koludricama u Zadar obrazlažući kašnjenje u izradi kipova, onda se može reći da je zadarski oltar dokumentiran na brojnim razinama. Iako je tijekom Drugoga svjetskog rata oltar teško oštećen u bombardiranjima, usprkos tome mramorni kipovi anđela sačuvani u fragmentima pokazuju visoke domete njegove umjetnosti. Zadarski oltar klasičan je primjer tabernakul-oltara kakav se u brojnim varijantama susreće tijekom 17. i 18. stoljeća u katoličkim crkvama, pa tako i u Dalmaciji gdje su ga unijeli mletački majstori. Morlaiter je istovjetan oltar sa svetohraništem na sredini mramornog stipesa i kipovima anđela s rubovima podigao u crkvi S. Maria della Fava u Veneciji između 


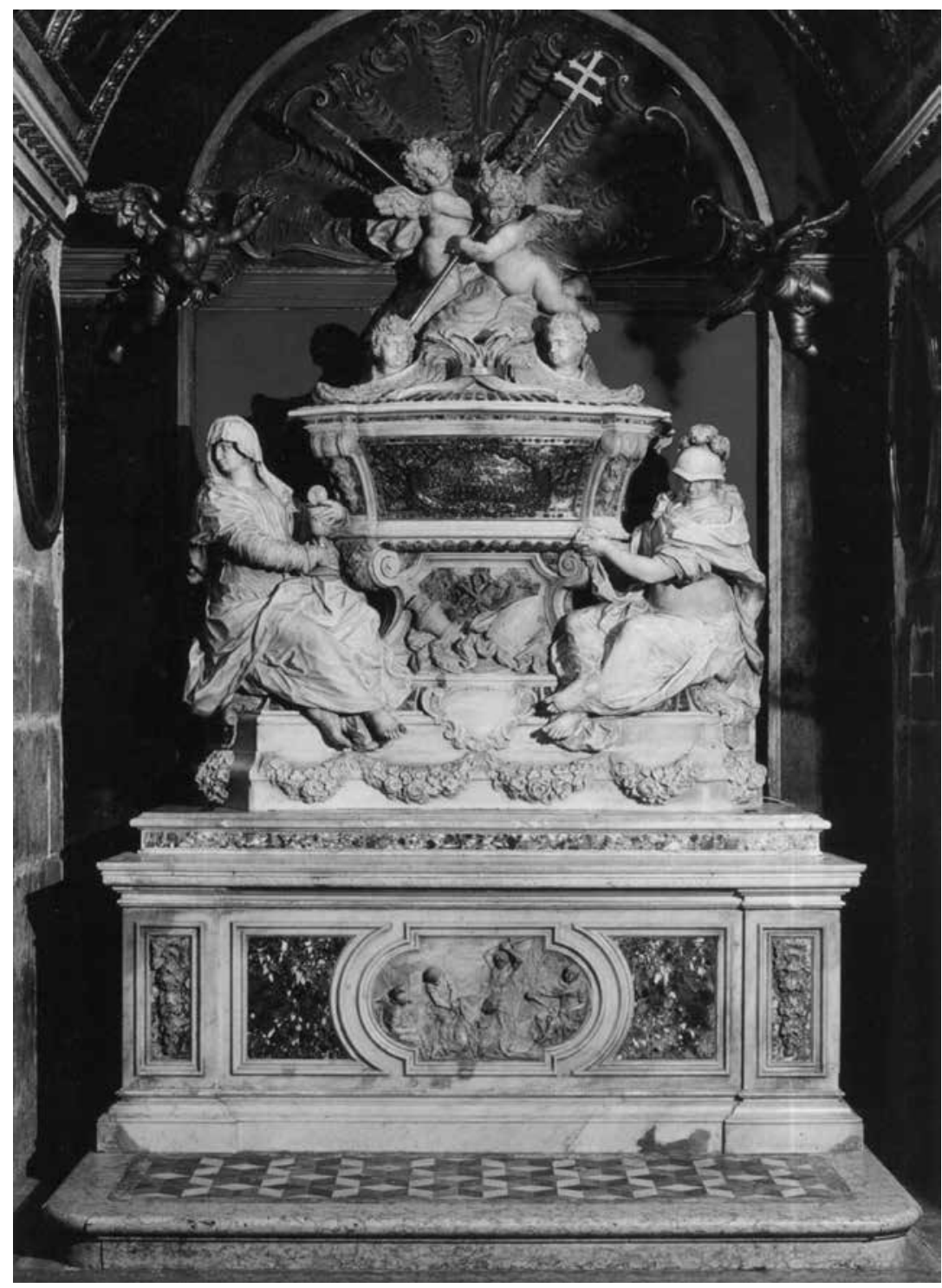

G. M. Morlaiter, oltar sv. Dujma, katedrala sv. Duje, Split G. M. Morlaiter, altar of St Doimo, Split, cathedral

1750. i 1755. godine. Tamošnji je oltar nastao prema zamisli arhitekta Giorgia Massarija s kojim je Morlaiter veoma često surađivao na brojnim projektima. On je složenije dekoracije jer uključuje reljefe u pozlaćenom srebru na predoltarniku, ugaonim pilastrima te na vratnicama svetohraništa, vrste mramora su brojnije i dragocjenije, a modelacija anđela klesanih u mramoru iz Carrare studioznija. ${ }^{23}$

Bojani terakotni modeli za zadarske anđele u Ca' Rezzonico visoki su 44, a mramorne skulpture na oltaru 155 centimetara. Može se reći da ti veliki gipsani radovi nisu bozzetti kojima je majstor isključivo skicirao stvaralačku ideju, nego modeli i predlošci koje je pokazao naručiteljima i njihovim opunomoćenim predstavnicima, a bili su, kao i spomenuti crtež, sastavni dio ugovora prema kojima su potom isklesani u mramoru. Vjerojatno kipar modele nije slao benediktinskim redovnicama u Zadar jer su u njihovo ime posao ugovarali prokuratori, članovi obitelji Fanfogna koji su ih sigurno vidjeli u njegovoj radionici u
Veneciji. Koludrice su mogle vidjeti upravo crtež koji im je mogao predočiti budući izgled glavnog oltara u crkvi koju su 1744. temeljito obnovile i ukrasile štukaturama za što je bio angažiran Giuseppe Monteventi. ${ }^{24} \mathrm{Da}$ bi postavili novi oltar Lorenza Bona i Giovannija Marije Morlaitera, redovnice su 1742. godine dale ukloniti stari ciborij što ga je dao podići kralj Koloman te su istovremeno porušile tri apside i na njihovu mjestu sagradile kvadratno svetište s kupolom na okruglom tamburu. Tako je stara crkva dobila posve novi, moderan izgled u kojemu je mramorni glavni oltar uglednoga mletačkog kipara postao najljepši ukras. Ako se zadarski anđeli sagledaju u okviru majstorova ukupnog korpusa anđeoskih figura, onda oni naglašenim volumenom, blago zarotiranim pokretom, složenom strukturom nabiranja draperije i arhaiziranim osmjehom na mekom i glatkom licu pokazuju kako je Morlaiter tijekom cijele karijere neznatno mijenjao rukopis rješavajući na sličan način vlastite umjetničke opsesije. 
Posebnu vrijednost u korpusu mramorne skulpture 17. i 18. stoljeća u Dalmaciji ima nadgrobni spomenik vojnog inženjera i zapovjednika Giovannija Francesca Rossinija (1686.-1764.) postavljen na sjevernom zidu u svetištu crkve sv. Šimuna u Zadru.

Spomenik je podignut nakon Rossinijeve smrti 1764. godine. Oblikovan je u kombinaciji bijelog i crnog mramora u formi oltarnog retabla s profiliranim konzolama na koje se naslanjaju bočni pilastri ukrašeni u gornjem dijelu visećom girlandom od stiliziranih ljiljana. Između pilastra je niša lučnog završetka s kalotom u kojoj je na visokom, dvočlanom i izvijenom postolju pokojnikova bista. Kao zapovjednik (sergente maggiore di battaglia) Rossini je u vojničkoj odjeći ogrnut draperijom privezanom u čvor na lijevom ramenu. Njegovo je staračko lice naboranih obraza i visoka čela, istaknuta nosa, upalih očiju i naglašenih obrva s vlasuljom meko modeliranih gustih uvojaka koji padaju na ramena. Uz podnožje su posloženi atributi Rossinijeve djelatnosti: knjige s nacrtima, papir za crtanje, kutomjer, šestar, globus, ravnalo te kaciga s perjem.

Između profiliranih konzola na crnoj mramornoj ploči upisan je epitaf:

$$
\text { D. O. M }
$$

D. S. P.

IOANNI FRANCISCO ROSSINI GALLO NARBONENSI VENET: MILITVM PRAEF. GRĀLI PROPVGNATORIAE MAGISTRO

ET BELLI ET PACIS PRAESTANTISSIMO

ARCIBVS IN VENET: ITALIA EPŸRO ET DALMATIA INSTITVTIS AVCTIS INSTAVRATIS EMENDATIS DE REP: VEN: SIBI VSQVE MVNIFICENTISSIMA BENEMERITO

EFERVESCENTIBVS JADRAE ASCIVŸQVE SVIS INSTAVRATIONIBVS

PVBLICO FATO PEREMPTO

ALOŸSIVS FRACHIA MAGNANI PRAEF: GRALIS AC NIC: CO: DE RIGO

TRIBVNVS MILITVM.

\section{CVRATORES EX TESTAMENTO POSVERE} VIXIT ANNOS LXXVII

OBŸT JADRAE XI KAL: MAII MDCCLXIIII.

Morlaiter je bio sposoban portretist. Pronicavo je znao uočiti tjelesne i duhovne odlike portretirane osobe, zapaziti emocionalnu strukturu i slojevitost njezina duha, što je potom, krećući se u okvirima vlastitih mogućnosti i stilskih konvencija vremena i sredine, modelirao u glini, terakoti i klesao u mramoru i kamenu. Njegovo tumačenje ljudske fizionomije vodi brigu o cjelini i pojedinostima. Pri modelaciji Rossinijeva lica dubokim borama ocrtao je iscrpljenost i umor staračkih godina dok su kaligrafski definirane oči naglašenih zjenica besciljna pogleda. ${ }^{25}$

Morlaiter je višekratno izrađivao u glini i terakoti bozzette i modele. Tako je i za Rossinijev portret izradio gipsani

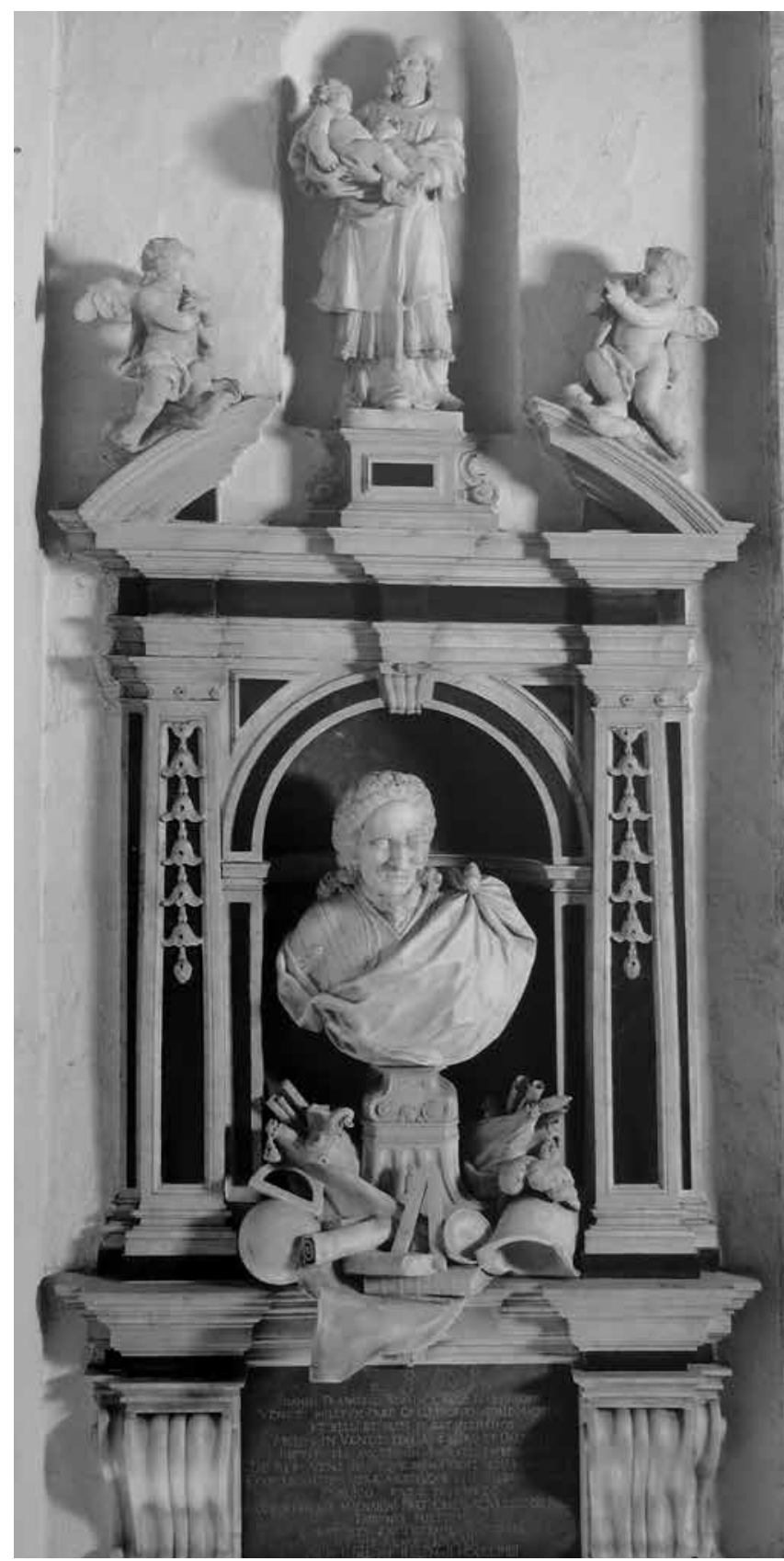

G. M. Morlaiter, Grobnica F. Rossinija, crkva sv. Šime, Zadar G. M. Morlaiter, Tomb of F. Rossini, St Simon's church, Zadar

model i prema njemu mramorno poprsje. S obzirom na to da je Morlaiter intenzivno modelirao u glini (nepečena i pečena glina, terakota) na tu temu treba reći da je riječ o umjenikovim vlastoručnim djelima koja se mogu odrediti u prvom redu kao modeli. Termin bozzetto (od tal. abbozzare) označava skicu koja opredmećuje kreativnu zamisao i koristi je u prvom redu umjetnik i njegova radionica, dok je model predložak koji se pokazuje naručitelju i prema kojemu se izvodi djelo u trajnijem materijalu. ${ }^{26}$

Kako je kipar izveo Rossinijev portret? Morao ga je izraditi prema nekom predlošku, vjerojatno prema slikanom prikazu pokojnika što su ga njegovi nasljednici mogli dostaviti kiparu 


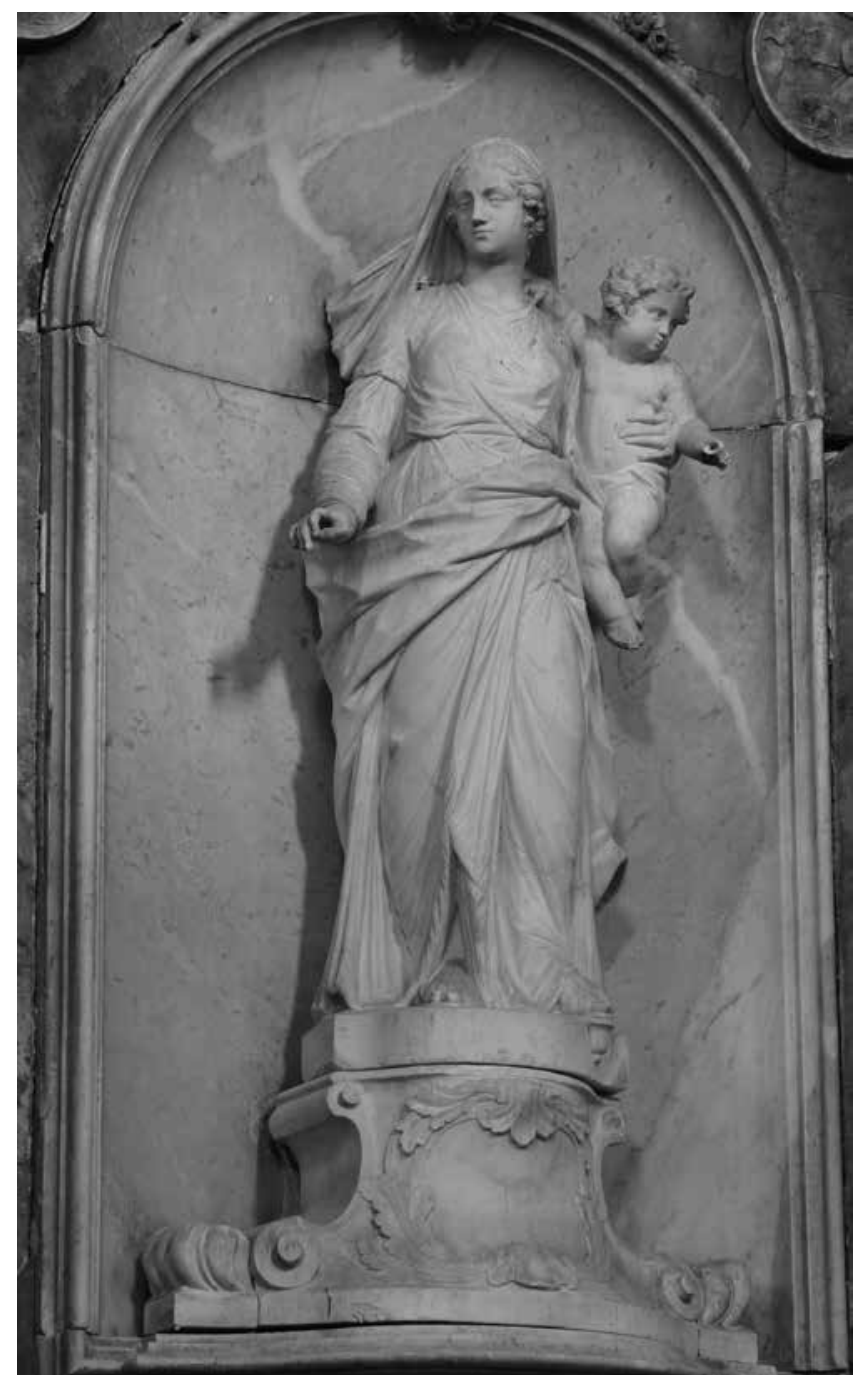

Gregorio Morlaiter, Gospa od Presvetoga Ružarija, oltar Gospe od Ružarija, crkva sv. Eustahija, Dobrota

Gregorio Morlaiter, Our Lady of the Holy Rosary, altar of Our Lady of the Rosary, St Eustace's church, Dobrota

u trenutku kada je odlučeno da mu se podigne spomenik u sjeni oltara s relikvijama sv. Šimuna. ${ }^{27}$

$\mathrm{Na}$ vrhu grobne edikule postavljena su tri kipa: na središnjem postolju je sv. Šimun s Djetetom u rukama, a sa strane na obratima zabata dva anđela kleče na oblacima i mole. Koncipirajući lik sveca zaštitnika crkve u kojoj je Rossinijeva grobnica podignuta, Morlaiter se vratio i varirao svoje rano istoimeno djelo iz 1729. godine u crkvi San Vidal u Veneciji. ${ }^{28}$

Zašto je Rossinieva grobnica podignuta u crkvi sv. Šimuna? Treba se podsjetiti da crkva sv. Stjepana nosi naziv sv. Šimuna tek nakon što je u nju prenijeta škrinja sa svečevim moćima 1632. godine. Prijenos svečevih moći i njihovo izlaganje na monumentalnom oltaru završenom, kako je zapisao Daniele Farlati, tek 1672. godine pretvorilo je tu crkvu u važno i popularno svetište ne samo u Zadru i cijeloj Dalmaciji nego i kod službene mletačke vlasti i njezinih predstavnika u Zadru. Budući da je u neposrednom susjedstvu crkve Providurova, Kneževa i Kapetanova palača, ona je postala
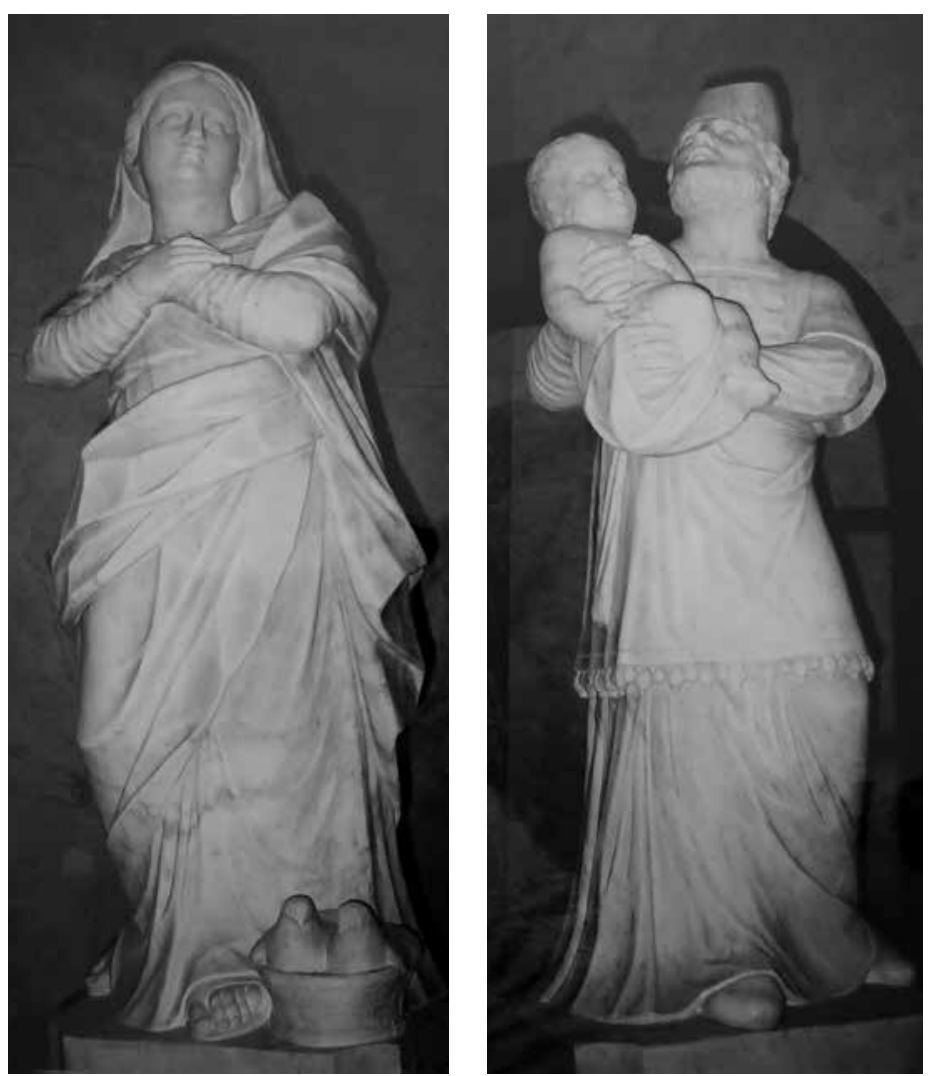

Kipovi sv. Ane i sv. Šimuna, župna crkva Očišćenja Bl. Dj. Marije, Dol, otok Brač

Statues of St Anne and St Simon, parish church of the Purification of the Blessed Virgin Mary, Dol on the island of Brač

državna crkva, »providurova, kneževa i kapetanova kapela « po uzoru na duždevu kapelu, crkvu sv. Marka u Veneciji. U njoj su se obavljale brojne vjerske funkcije vezane uz predstavnike političke i vojne moći. U tom smislu treba shvatiti da je 1675. godine novoosnovana bratovština hrvatskih i albanskih vojnika našla sjedište upravo u crkvi sv. Šimuna, u kapeli sv. Jeronima gdje je tom svecu podignut mramorni oltar. ${ }^{29}$ Prijenos svečevih moći, izgradnju njegova oltara, opremanje svetišta i osnivanje bratovštine vojnika određivali su i provodili gotovo u pravilu predstavnici državne vlasti, a ne zadarski nadbiskup i kaptol. Tako se uz crkvu sv. Šimuna povezala politička i vojna 'oligarhija' koja je, čini se gotovo u potpunosti vodila brigu o njezinoj opremi. Stoga je podizanje grobnice istaknutom vojnom inženjeru i naredniku G. F. Rossiniju u toj crkvi, u svetištu i u neposrednoj blizini svečeva oltara u tom kontekstu logično i razumljivo.

Upravo zbog sposobnosti da vješto i vjerno izradi portret, Morlaiter je dobivao brojne narudžbe za nagrobne spomenike u Veneciji i na širem prostoru Mletačke Republike. Iz ranoga umjetnikova razdoblja (1729.) potječe grobnica Giovannija Battiste Colloreda (Colloredo di Montealbano, župna crkva) na kojoj je pokojnikov lik prikazan u plitkom reljefu, u profilu s perikom i realistično modeliranim licem. Nekoliko godina nakon toga, oko 1734. Morlaiter je u oratoriju vile Lattes (Istrana) u ovalnom medaljonu izradio portet u reljefu Paola Tamagnina, što će 1756. ponoviti i na spomeniku generalu 


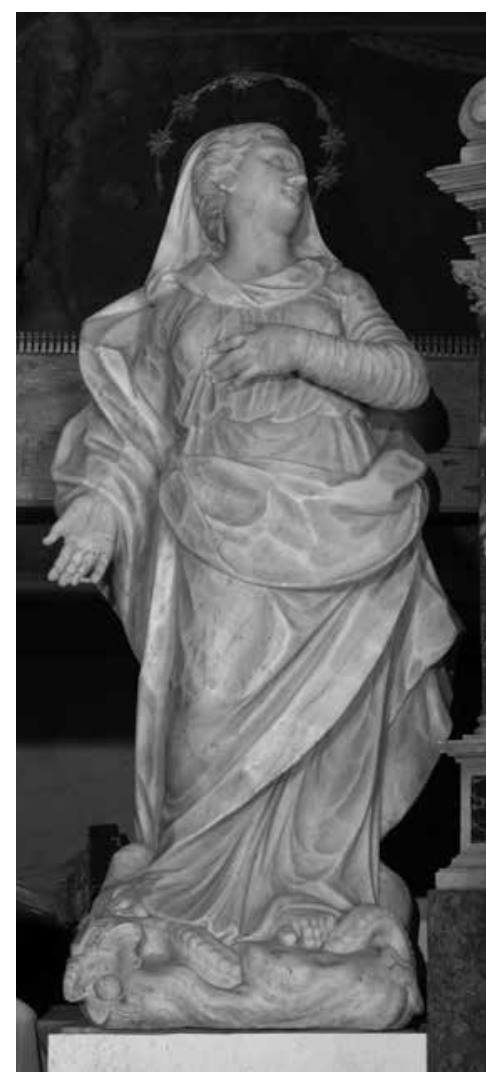

Bogorodica, ž. c. Uznesenja Bl. Dj. Marije, Katuni (Omiš)

Madonna, parish church of the Assumption of the Blessed Virgin Mary, Katuni (Omiš)

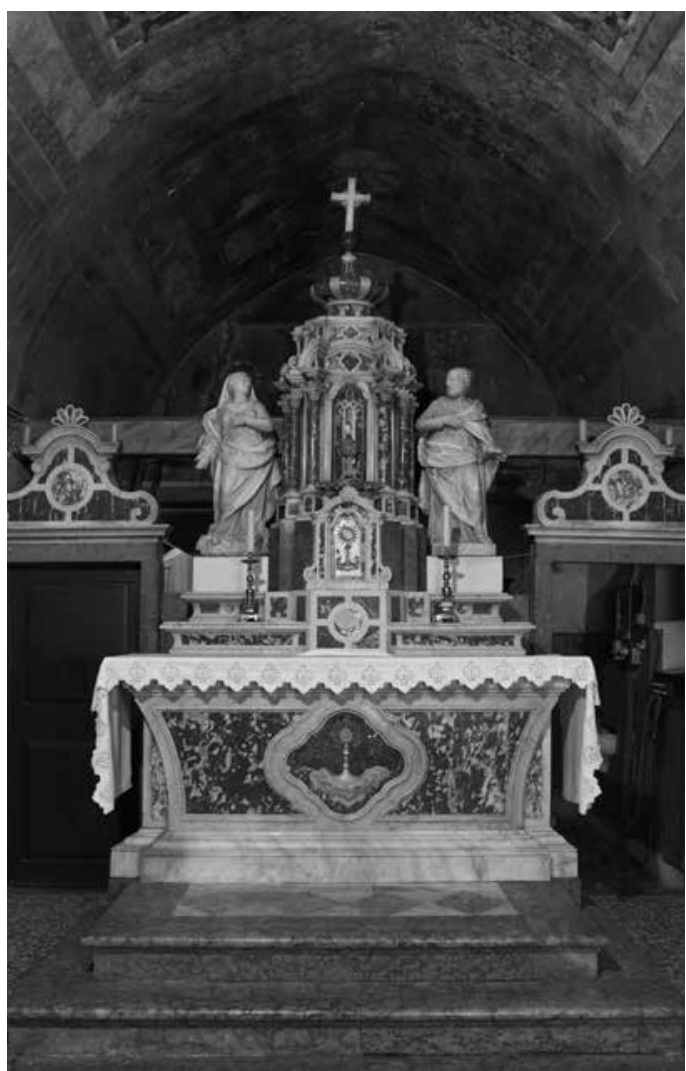

Glavni oltar, ž. c. Uznesenja Bl. Dj. Marije, Katuni (Omiš)

Main altar, parish church of the Assumption of the Blessed Virgin Mary, Katuni (Omiš)

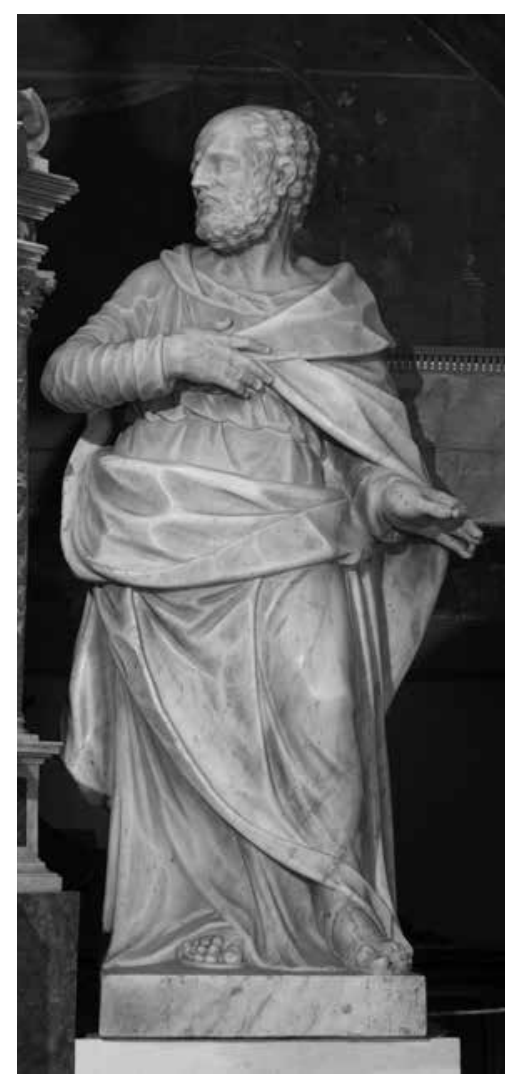

Sv. Josip, ž. c. Uznesenja Bl. Dj. Marije, Katuni (Omiš)

St Joseph, parish church of the Assumption of the Blessed Virgin Mary, Katuni (Omiš)
Matthiasu von der Schulenburgu na Arsenalu u Veneciji. I njegovo je poprsje s perikom i paradnom odjećom postavljeno $\mathrm{u}$ ovalnu pozadinu kao i portret G. B. Colloreda te dopunjeno simbolima i atributima slavne vojne karijere. ${ }^{30}$

Za dalmatinske naručitelje radio je i njegov sin Gregorio Morlaiter (1738.-1784.). Prema objavljenom dokumentu on je 1777. godine trebao izraditi oltar sa svetohranišstem i kipovima anđela za katedralu sv. Tripuna u Kotoru. ${ }^{31}$ Zabilježen je i njegov angažman na oltaru sv. Vinka u crkvi sv. Dominika u Zadru (danas u katedrali sv. Anastazije u Zadru). ${ }^{32}$ No najvažnije je da se upravo Gregoriju Morlaiteru pripisuje mramorni kip Gospe od Presvetoga Ružarija na istoimenom oltaru u crkvi sv. Eustahija (sv. Stasija) u Dobroti kraj Kotora u Boki kotorskoj. Oltar i kip dovršeni su 1774. godine prema narudžbi uglednih dobrotskih kapetana. ${ }^{33}$ Kip postavljen u središnju nišu nastao je prema uzoru na istoimeno djelo koje je između 1721.i 1723. godine isklesao Antonio Corradini za crkvu delle Eremite u Veneciji, dok se zbog nekih konkretnih sličnosti spominjao i Corradinijev kip Djevičanstvo u crkvi S. Maria dei Carmini iz 1721. godine. ${ }^{34}$ Tome se opravdano može pridodati i maleni kip Gospe od Ružarija koji je za crkvu S. Maurizio u Veneciji izradio, smatra se, Giovanni Maria Morlaiter i suradnici u kasnom razdoblju djelatnosti. Za taj je kip sačuvan i glineni model na ovalnom postolju s ugaonim volutama što se $\mathrm{u}$ sličnom obliku ponavlja na oltaru u Dobroti. ${ }^{35}$
Iz radionice majstora koji se izravno inspirirao Morlaiterovom umjetnošću sačuvano je nekoliko kipova u dalmatinskim crkvama. Postavljeni su na oltare koje su podizali majstori iz obitelji Bruttapelle (Bertapelle). Na glavnom oltaru crkve u Dolu na otoku Braču sa strana monumentalnoga dvokatnog svetohraništa nalaze se kipovi Bogorodice i proroka Šimuna. Dok se Bogorodica načelno uklapa u tipologiju Morlaiterovih svetica, dotle je prorok Šimun reducirana varijata njegova kipa u crkvi San Vidal u Veneciji, ili istoimena kipa na Rossinijevoj grobnici u Zadru. Oltar je prema dokumentima podigao majstor Petar Pavao Bruttapelle 1778. godine, a proširio Battista Caron početkom 19. stoljeća. Kipove Bogorodice i proroka Šimuna na oltar postavio je Bruttappelle 1789. godine, ${ }^{36}$ što bi značilo da je kupovao gotova djela u Veneciji te ih postavljao na žrtvenike koje je podizao u gradskim i seoskim crkvama srednje Dalmacije. To se odnosi na kvalitetnije slobodnostojeće mramorne skulpture dok su plošno rezani, statični i beživotni kipovi anđela i svetaca, dekorativni reljefi i girlande na njegovim žrtvenicma nastajali u obiteljskoj radinici u Vrboskoj na Hvaru.

Morlaiterov 'utjecaj' potvrđuju i kipovi Bogorodice i sv. Josipa na glavnom oltaru stare župne crkve Uznesenja Blažene Djevice Marije u Katunima u omiškom zaleđu te kipovi anđela u kapeli sv. Vincenze u župnoj crkvi u Blatu na Korčuli. Oltar u Katunima opremao se od 1774. do 1789. godine: 1774 . 


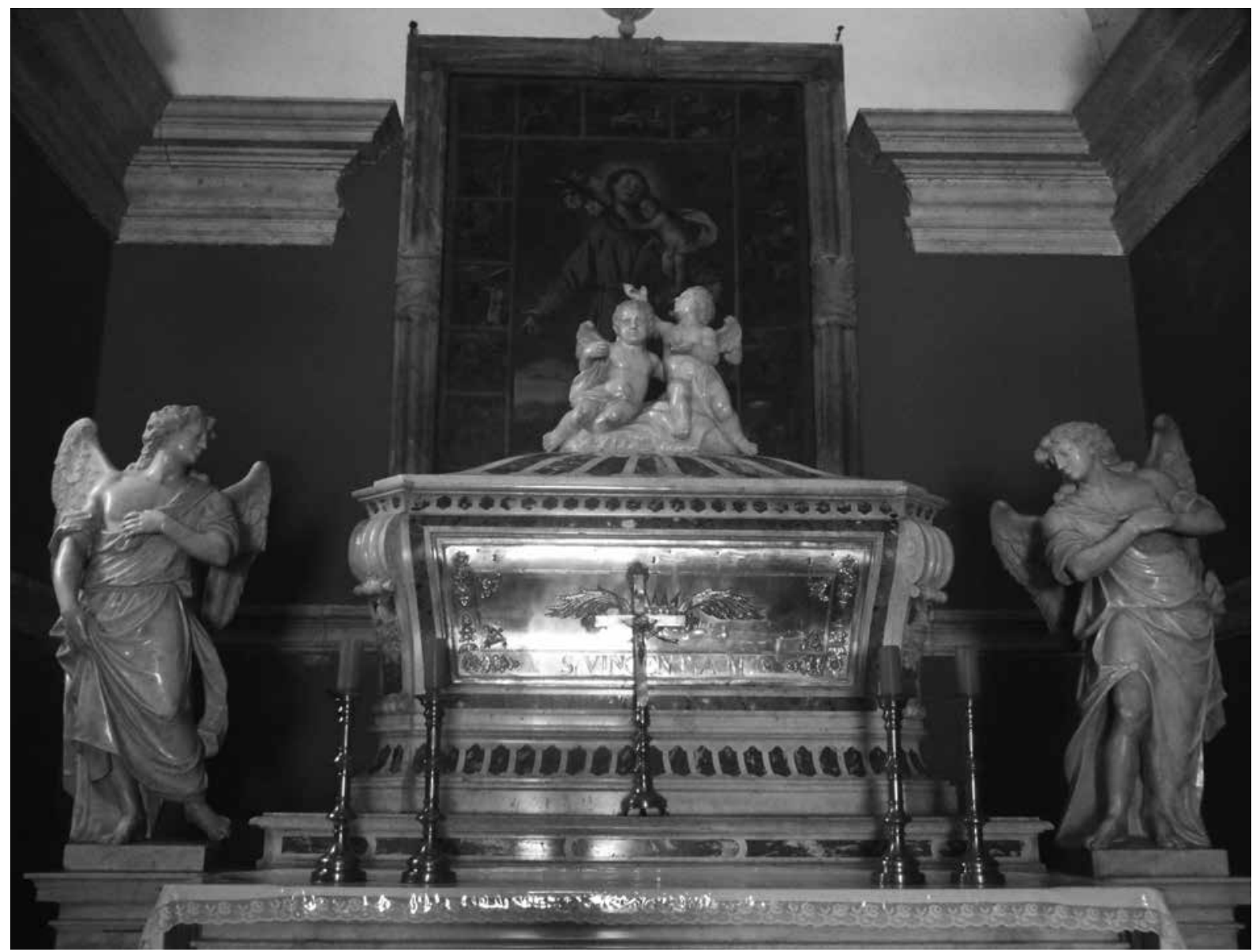

Paolo Bertapelle (Bruttapelle), oltar sv. Vincence, ž. c. Svih Svetih, Blato na Korčuli

Paolo Bertapelle (Bruttapelle), altar of St Vincenca, parish church of all Saints, Blato on the island of Korčula

kupljeno je svetohranište, iduće godine uređene su stube dok je stipes s predoltarnikom i menzom nabavljen 1777./1778. godine. Mještani su 1783. odlučili kupiti mramorne kipove $\mathrm{u}$ Veneciji, što im je odobrio providur u Omišu, ali oni su stigli tek 1789. godine, ${ }^{37}$ dakle istovremeno kada i u nedaleki Dol na Braču. Oba kipa stilizacijom i ritmom oštrorezanih nabora, položajem tijela i kretnjama, proporcijama i odnosom pojedinih dijelova upućuju na Morlaitorova rješenja koje je anonimni mletački majstor vidio i preuzeo iz njegova repertoara. Vjerojatno je i ovdje upravo P. P. Bruttapelle bio posrednik u kupnji mramornih kipova za župnu zajednicu koja je okupljala veliki broj vjernika u selima oko rijeke Cetine.

Sličan je bio tijek opremanja oltara sv. Vincenze u Blatu na Korčuli. Altaristi Paolo i Antonio Bruttapelle za gradnju žrtvenika isplaćivani su od 1799. do 1816. godine. U isplatama se navodi da žive u Vrboskoj na Hvaru. ${ }^{38}$ Oltar s izvijenim trbušastim predoltarnikom u gornjem dijelu ima raku s metalnim vratnicama i anđelima na poklopcu, dok su kipovi anđela postavljni bočno na uvučena visoka postolja. Upravo ti anđeli na kojima se jasno ocrtavaju odlike klasicizma još uvijek u ritmu pokreta, stilizaciji draperije i obradi kose upućuju na Morlaiterove kipove koji su anonimnom mletačkom majstoru kod kojega su kipovi kupljeni služili kao model i predložak, potvrđujući na taj način kako je bila poticajna i živa njegova umjetnost. ${ }^{39}$ I tipologija žrtvenika oslanja se na Morlaiterov rad: Bruttapelle su se za oltar u Blatu izravno inspirirali žrtvenikom sv. Duje u splitskoj katedrali jer se na oltaru sv. Vincence ponavlja oblik rake s metalnim vratnicama, ugaonim volutama i poklopcem iz kojega izravno izlaze glave anđela. Takav tip sarkofaga s anđelima na poklopcu Morlaiter je izradio i na oltaru San Giovanni Elemosinario sa svečevim relikvijama u mletačkoj crkvi S. Giovanni in Bragora. ${ }^{40}$

\section{Prilozi}

1.

\section{Dokument o anđelima za župnu crkvu Rođenja Blažene Djevice Marije u Prčanju}

Per li tre Angeli che sara (...) al Altare della Beata Vergine del S.S. Rosario in Persagno

Importar degli meddesimi per spesa di Pietra di Vicenza Scoltura per li stessi Pattinatura Oglio per spesa della Patina 

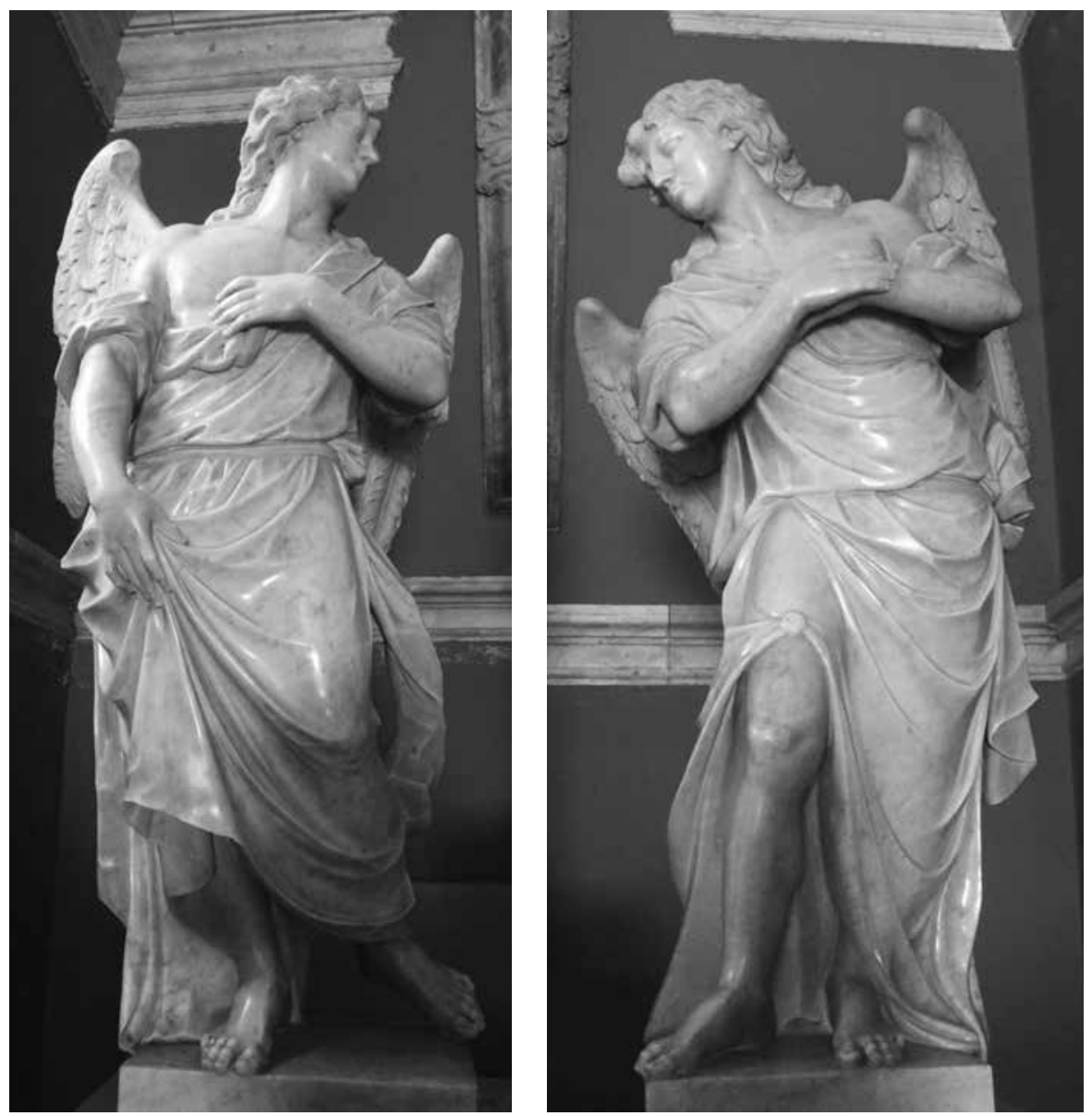

Anđeli s oltara sv. Vincence, župna crkva Svih Svetih, Blato na Korčuli

Angels from the altar of St Vincenca, parish church of all Saints, Blato on the island of Korčula

e fatura in tutto Ducati settantasei che son Lire quatro cento sattantadue è soldi quatro dico 471-4 Riceutti in tre volte lire tre cento e novanta tre dico 393:Resta 30 ottobre 1746 Ve.tia

(?) Io Gio Maria Morlaiter Scultor del Sig. E Tomaso per la spesa ocorsa ancora de cose fate fare ed per altre spese di feramenta e per cio di tutto e con la suma di lire quatro cento sesanta sei dico

L 462

\section{2.}

Dokumenti o glavnom oltaru u crkvi sv. Marije u Zadru

\section{Dok. 1 / recto}

Copia

Adi 22 Settembre 1759. Venezia

Nota per spese e fatture da farsi da me sottoscritto, per fa un basamento alla Romana con suoi Gradini e Tabernacolo con qui dichiarito conforme il dissegno.

Per far li 3. Scallini del sudetto Basamento saran fatti di mandola di Verona con suoi Regoloni all'impianto dalli due guariselli, et anco che circonda il di di dietro all'impianto del Tabernacolo, e far sua pradella rimessa di macchie triangolari, far sua Bassa, parapetto, Cimasa, alette, e due Pilastri del sopradetto Parapetto, e far due gradini per li Candellieri, e far il Tabernacolo con due impianti di quariselli, Custodia, Basse delle Colonne, e far N.o 6. Colonne di diaspro di Sicilia, a far la sua Nichia in Comparti di Verde antico, e diaspro di Sicilia, suo Architrave, fregio e cornice, suo laticinio, Gusa e Cuba, il tutto rimesso di diaspro di Sicilia e Verde Antico, e il tutto hà da esser fatto conforme il dissegno, importa la indetta operazione tra spesa di material, e spesa di fttura di Tagliapiera, e lustradura e segadura Ducati due mille e due Cento.

Dico di sola fattura di Tagliapiera

Duc: 2200:Più per far il salizo Bianco, e Rosso di Verona, e suo/uno (?) scallin di Mandola di Verona, il tutto lustrato importa Duc: sessanta due dico \begin{tabular}{l} 
Duc: $62:-$ \\
\hline Duc: 2262:-
\end{tabular}

\section{Dok. 1 / verso}

Suma Trasportata

Duc: 2262:-

Più per far il Balaustro conforme il dissegno di marmo di Carrara, il tutto lustrato tra spesa e fattura importa Ducati Cento e Cinquanta otto, dico

Duc: 158:-

Suma Duc: N:o 2420:- 
Co: Giuseppe Ant:o Fanfogna aff:mo per Duc: o 2?00

Io Lorenzo Bon Tagliapera aff:mo

Per far due Angioli laterali al med: mo Tabernacolo di marmo di Carrara, della Grandezza à raguaglio del dissegno, più li due puttini, e seraglia sopra la nichia, così la Cima della Custodia dissotto, il tutto per spesa e fatt:a accordato dal Ill:mo Sig:r Conte per prezzo di Ducati Settecento..... dico.....Duc:- 700:-

Restando in arbitrio del sud:o Sig:r Conte il dimostrarne alla Consegna della sunominata opera quel segno d'aggradimento, che può gli sarà di piacere, qual valerà sempre più à stimolo d'incontrar ciò che aggradisca, e assieme soccorrere l'accordo seguito, in fede di ciò sarà sottoscritta dalle Parti. Co: Giuseppe Ant: Fanfogna aff:mo senza l'espresso arbitrio Io Gio: Maria Morlaiter, scultor aff:mo qunto di sopra.

\section{Dok. 2}

Lorenzo Bon Tagliapiera

\section{Devon Havere}

Per accordo stipulato in Venezia da far un Basamento alla Romana con suoi Gradini e Tabernacolo etc dell Altar nuovo in S. Maria delle Reverende Monache in Zara

Ducati 2300 fanno Z 14260:-

$\mathrm{Si}$ (?) la summa contrascritta

per saldo

$\underline{\mathrm{Z} 12010}$

Addi 4 Agusto 1762:3250

Contati Cech: $\mathrm{N}^{\circ}$ 30- Sono

Devon Haver A per Saldo

a 18 Ag.to C.i 15:Z 330

a 21 Ag.o C.i 15: Z 330

Devon Haver per Saldo Z

Più 1. (di) 24 Ag.o C.i 15

Devon Haver per Saldo Z

$\frac{\mathrm{Z} 12010}{3250}$
$=\quad \underline{1990}\left(1 \frac{660}{590)}\right.$

Devon Dare

1760. 19. Feb: per ricevuti dal Sig.r Co: Fran:co

Fanfogna

Z 1540:-

1760. 18. Giugno per ricevute dallo stesso $\quad$ Z 3300:-

1761. 14.April per ricevute dallo stesso

1761. 8. Maggio per rice:te dallo stesso

1761. 14. Maggio per ricevute dallo stesso

1761. 12. Giugno per ricev:te dallo stesso

1761. 14. Lug:o per ricevute dallo stesso

1761. 4. Agosto pr ricev:te dallo stesso

Z 1310:-

Z 400:-

Z 600:-

Z 500:-

Z 1800:-

Z 800:-

1761. 6. Dicembre: per ricevuto dallo stesso

Gio: Maria Morlaiter Scultor

Devon Haver

Per accordo come sopra fatto in Venezia per far due Angioli al sudetto Tabernacolo, due putini e seraglia sopra la nichia etc. dell Altar soprad:o

Ducati 700. fanno Z 4340:-
Devon Dare

1761. 14. April per ricev:te dal Sig:r Co:

Francesco Fanfogna

Z 1550

Z 330

Z 310

1761. 13. Giugno per ricev:te dallo stesso

Z 800

Piu senza ricevuta

$\bar{Z} 2990$

\section{Dok. 3}

Arivato (?) in Ven(eti)a li 30 Luglio 1762 per l' Altare di S. Maria (?)

Hò fari li seguenti Calcolati(?) sino il giorno d'oggi 24:Agosto

A Ill Mistro Lorenzo Bon Altarista in più volte $\quad$ C:i 75

Al Sig.re Morlaither Scultor in più volte $\quad$ C:i 40

Per la Croce Dorata Sazio (?) deve per (?), ela C (?) C:i 5

All'Intagliador a Conto C:i 6

Al Favro a'Conto C:i 6

Cassella Foder, Labarin (?) $\quad$ C:i 6

Per Madri di Santa Maria per il Suo Altare

Devon Dare

Accordo di Altarista D:i 2300 sono Z 142 ?0

Accordo del Statuario D:i 100 sono Z Z 4340

Summa $\bar{Z} 186 ? 0$

Per la Spesa de G (?) e Candelieri, Croce (?) e Candele $\lcm{366}$

Le Madri Per Contati in (?) e spediti in Ven:a

Devon Haver

Co (?) 682

Z 14894

Al Co: Clero (?) ? Cech.i 64 2/4 sono

Contati Nel ? ato (?) L ? C.i 116

18865

Le M.M. Sta Maria per Spediti, e Caluli (calcoli?)

D.D.r come segue

C.i 682 sono

Z 15004:

S. Co. C(?) ? in Zara $1419 \quad$ Z 16423:-

Contati a un C.i 116

Z 2552

18975

\section{Dok. 4}

Per l'Altar Nuovo da farsi in S:ta Maria

Devon Dare

All' Altarista Lorenzo Bon, giusta la Polizza dell'accordato Ducati due Mille e Trecento, fanno Z 14269:-

Al Statuario Gio: Maria Morlaiter similm:te giusta la Polizza dell' accordato Ducati Settecento..........fanno.................Z 4340:-

Più per la spesa de Lattoni (?)

Suma Z $18966:-$

Restano dar per l'intiero

Z 16432:-

Devon Havere

Per Contati à conto in più volte, e in diversi tempi, come appar dalle Ricevute, Cecchini settecento quaranta sei, e mezzo.....fanno Z 164 23:- 


\section{Dok. 5}

Notta delle spese di S. Maria.

4 Agosto à Mistro Lorenzo Bon Cechini N 30

9 d:to: Morlaiter Cechini N 15

14 Agosto al Sig. Morlaiter Cechini N

No: 15

18 d:to à Mistro Lorenzo Cechini N 15

21 d:to: al Sig. Morlaiter Cechini N 10

Mistro Lorenzo Bon Cechini N 15

24 d:to: à Mistro Lorenzo Bon Cechini

$\mathrm{N}$

28 d.to al Sig Morlaiter per saldo

del suo aveva Cechini $\mathrm{N}^{\circ}$ : 32:Dto: $\mathrm{N}^{\circ} 2$ :

28 d: to: a Mistro Lorenzo Cechini N 10:

D:o Settembre: à M:o Lorenzo Cechini N 6:

Per Intiero Saldo Sono

segue altra spesa.

Per una Caseta di Nogera intera

Drapo per fodrala $B^{a}: 2: d^{\mathrm{i}}: j: \mathrm{Z} 21: 10$ :

all'intagliata

Per una Croce fatura, e indora:

dura, come apar dalla ricevuta

più al medesmo a' conto delle

altre fature

al Fauro per conto delli Brasaleti,

che va' facendo

per il crivello di Calcina

per piombo $\mathrm{N}^{\circ} 18$

per due sachi novi

del Mistro che ha fodrato

la Custodia, e la Portella

primo setembre 1762 per saldato il conto

di legname, fatura, a peatta,

a Mistro Lorenzo Bon, come apar

dalla polizza saldata con

Incontro da Conti Con S. ${ }^{a}$ Maria.

Santa Maria Devon Haver per Spediti in Giugno

1760

C.i

Per Spediti in April

761

Più Contati in Zara

Per Spediti in Giugno

761

più Contati in Zara

Per Spediti in Luglio

761

Per Spediti in Agosto

761

Più Contati in Zara

C.i

C.i

C.i

C.i

C.i

C.i

Più Contati in Zara in Genaro

762

C. $i$

Più Contati in Zara in Magio

762

$\mathrm{C}$

Summa No.

C.i

C.i
Santa Maria Devon Dare

Per Contati in Ven. ${ }^{a}$ al Mistro Lorenzo Bon

$\mathrm{Z} 660:+$

Taglia Pietra in Febraro:

1760

Per Contati allo Scultor in Giugno

760

Z 330 : Contati allo Scultor in April

Z 330 : 761

Z 220 : più al Sudeto Tagliapietra

$\mathrm{Z} 330$ : più allo stesso in Maggio

No: 15 Z $330: \quad \frac{761:}{\text { allo stesso in Maggio }}$

Z 720: 761:

Z 220: in Maggio allo Scultro

761:

Z 380: - Contati al Taglia Pietra Giugno

761

Z. 8:- $\quad 761$

Scultro in Giugno

Per Saldo de latoni (?)

Z 132: $\quad 761$

Al Taglia Pietra in Luglio

Z 100: 761

Z 1540:-

Z 3300

Z 1550:

1310

400

600

330

500

310

366

1800

800

1760:

Z 132: 761

Allo stesso in Agosto

Allo stesso in 7bre

Z ?: Alo Scultro in Maggio

Z 9: 762

Z $5: 10$ Summa

$\frac{880:}{15446}$

Z 9: Dok. 6

Sig:R Conte Fran:co Fanfogna

Z 521:10

Devon Dare

1760. 17. Giugno per ricevuti dal

Glavasovich a nome del Bianchini

1761. 11. April per ricevuti dal Scagliarin

1761. 13. April per ricevuti dallo stesso

Per ricevuti in Zara Sig.r Co: Giuseppe

180

20:

Più per ricevuti in Zara lo stesso

S:r Co: Giuseppe

1761. 8. Giugno per ricevuti dal sud:o

Scaglarin

26:-

1761. 26. Lug:o per ricevuti col Caichio

Felicinovich

65:-

1761. 13. Agosto per ricevuti dal

Vlassanovich

75:-

12:-

Più per ricevuti in Zara Sig:r Co:

Giuseppe

50:-

142

Più per consegnati al S:r Co: Fran:o in Zara per spedir a Venezia

Più per consegnati allo stesso in oro,

Petizze e mon:a

Cecch:i 200:-

Cecch:i 50:-

Cecch:i 130:-

Cecch:i 20:-

Cecch:i 26:-

Cecch:i 104:-

Cecch:i 65:-

Cecch:i 75:-

Cecch:i 12:-

Cecch:i 50:-

Cecch:i 14 1⁄2

Cecch:i $746^{1 / 2}$

16423:-

15446

Fanno 
D. H:r

1760. 19. Feb: per Con:ti al Tagliapera Lorenzo Bon

1760. 18. Giugno per Conte al sud:o

1761. 14. April per cont:e al scultor Morlaiter

D:o per Cont:e al Tagliapiera sud:o

1761. 8. Magg:o per Cont:e allo stesso

1761. 14. Magg:o per Cont:e allo stesso

1761. 15. Magg:o per Cont:e al Scultor sud:o

1761. 12. Giugno per Cont:e al Tagliapiera sud:o

1761. 13. Giugno per Cont:e al Scultor sud:o

1761. 14. Lug:o per Cont:e al Tagliapiera

1761. 4. Agosto per Cont:e allo stesso

1761. 6 xbre: per Cont:e allo stesso

Più per Cont:e al Scultor sud:o senza ricevuta

1761. 17. Lug:o Più la spesa de Lattoni (?)

Z 15000:-

Z 366:-

Z 15366:-

Le Madri di Santa Maria

Devon Haver

1760. 17. Giugno per Spediti a Venezia al

Sig:r Co: Fran:co Fanfogna col

Glavazevich a nome del Bianchini

1761. 11. April per spediti allo stesso col Scagliarin

1761. 13. D:o per spediti col detto

Per cont:i in Zara al Sig:r Co: Giuseppe

Più per Cont:i in Zara allo stesso Co:

Gius:e

1761. 8. Giugno per spediti col Scagliarin sud:o

1761. 26. Lug:o per spediti con Caichio

Felicinovich

1761. 13. Agosto per spediti col Paron

Vlassanovich

Per Cont:i in Zara al Sig:r Co: Giuseppe

Per Cont:i al Sig:r Co: Fran:co in Zara

Per Cont:i allo stesso in oro, Petizze, e mon.u

1762. 20. Lug:o per Cont.i in Zara Al Sig:r

Co: Giuseppe per saldar la scrittura dell'Altar

Più per supplire ad altre spese

Summa

Più una Verga al peso come sta segnata

Li cecchini fanno

Cecchi:i 200:-

Cecch:i 50:-

Cecch:i 130:-

Cecch:i 20:-

Cecch:i 26:-

Cecch:i 104:-

Cecch:i 65:-

Cecch:i 75:-

Cecch:i 12:-

Cecch:i 50:-

Cecch:i 14 1/2:-

Cecch:i 116:-

Cecch:i 40:-

Cecch:i 902 1/2:-

once N:o 40

Z 19855:-

\section{Devon Dare}

1760. 19. Feb: per Cont:i dal Sig.r Co:

Fran:co all' Altarista Lorenzo Bon

1760. 18. Giugno per Cont:e dallo stesso allos stesso Bon

1761. 14. April per Cont:e dal med:mo

All'Intagliador Morlaiter

14. d:o per Cont:e al sud:o Bon

1761. 8. Magg:o per Cont:e al med:mo Bon

Z 1550:-

Z 400:-

Z 600:-
1761. 15. Magg:o per Cont.e al Morlaiter sud:o

Z 330:-

1761. 12. Giugno per Cont:e al sud:o Bon

Z 500:-

1761. 13. Giugno per Cont:e al Sud:o Morliter

Z 310:-

1761. 14. Lug:o per Cont:e al sud:o Bon

Z 1800:-

1761. 4. Agosto per Cont:e allo stesso Bon

Z 800:-

1761. 6. Xbre: per Cont:e med:mo Bon

Più per Cont:e al sud:o Morlaiter, senza

ricevuta

Z 1760:-

Z 800:-

15000:-

1761. 17 lug:o Più la spesa de lattoni

Z 366:-

Z 15366

Co: Giuseppe Ant:o Fanfogna Affermo

Dok. 7

Laus Deo Maria et Ogni Santi ... Li 30 Luglio 1762: Umago (?)

Il mio viaggio di Venezia il prima intencone è per dar fine all'impresa dell' Altare di Santa Maria. Rifferita allo speciosi pretessi dalli Artefici Mistro Lorenzo Bon Altarista, e Gio: Maria Morlaither Scultore.

Doversi sollecitare le fatture, non pero facionate, alle perfeinate procurare imbarco, e dare il p..(?); Procurando, che Sin Solito in pronto, e deto imbarco, al ressiduo del Salizo, Scalini, Mensa, e Balaustri e spedito Capomistro, perche ponga in opera Tutte le cose giù dette, onde al giungere del Tabernacolo, vi si possa dar Mano senza ulteriore Dilacione. Si dovevano provedere tutti gli Materiali necessarj, per il più pronto Compim.to dell'opera Medesima, de quali Mancando Scottaghi(?) di Zara(?). Si dovera Incatrare (?) l'Adobbo dell'Altare, e fodoridure al Modo più facile, più Solido, più (?), e più decoroso, mentre della fattura di ferro, non sono persuaso; Per Suo Moltiplich(?) da Fori(?), Luchi (?) dovrano essere fe(?) li mezzi, per sua coperta per (?).

Mistro Lorenzo Bon quando haveva dato imbarco al vessilio de' la(?) che mancano, per Compim:to dell'Altare, riceverà il suo intiero Soldo, con Lire Venete de piccoli ... Z 2250 Saranno inoltre Conteggiate le Spese de' Cassoni, et imbarchi, a ch'batuto, spacato tiene per Detto Conto Li sarà fatto l'intiero suo saldo. Con quanto risulterà Creditore. Il Signor Morlaiter dato l'imbarco alle statue, haverà il suo saldo, Con ... Z 1350:-

Sarà a(?)olito, che la Cimasa dell'Altare, Penso che debba farsi di Marmo, per cui si convenire col Signor Statuario, e Bon Convenendo, per far la Statueta di Christo Risorgente, ò Ascendente, si farà la Croce di Marmo in relazione, e Buona (?) Concordessa dell' Altare.

Le Portele della Custodia, sara al peso dell'Altarista, così quella de'Balaustri.

Doverà effettuarsi si in (?) alla Combinazione dell' Addobbo,

Z 1540:- $\quad$ per che tutto Carici a dovere.

Si procederà imbarco, e si darà la più solecita espedizione.

Z 3300:- Quando sia e(?) esser e si ricrederà l' intaglio fatto, e sarà pre(?) conveciale rissoluzione, senza dilazione.

Epistolario primo. 


\section{Dok. 8}

Giornate di lavoro che si devono pagare a Mro Domenico Silan in Raggion di Z 6. al Giorno, e ciò da 5. 7bre: 1762 Partito da Ven:a, sino li 16 (?) xbre: che hà compito l'erezione dell' Altare in S.Ta Maria, e quel più, che passerà nel suo viaggio di ritorno per Venezia, non comprese le feste da 5. 7:bre sin tutto il mese stesso giornate il suo lavoro.

Detratte le feste, compreso anche il Viaggio Giorn:e N:o 19 Nel mese di 8 bre

Giorn:e N:o 24

Nel mese di 9bre

Nel mese di xbre. Sino ili 16

Giorn:e N:o 23.

Giorn:e N:o 13.

Somma

Giorn:e N:o 79

A Z 6. Come sopra G.e 79 importano

Havuti à conto

Resta H.r saldo

Per conto di sue spese Al Sig.r Ant:o M:a Doria Speciale in Zara à S.ta Marcella accordato in Z 2 m: V:al Guirno da dì 10. 7 bre:inclusive sino (?) li 17. Xbre: inclusive sono

Nel mese di 7bre:Giorni N.o 21.

Nel mese di 8bre:Giorni N.o 31.

Nel mese di 9bre:Giorni N.o 30.

Nel mese di 7bre:Giorni N.o 17.

Giorni N:o 99 importano

Date a conto

Resta per saldo

Santa Maria di Zara

Notta delli Contamenti fatti

\section{Agosto}

Mistro Lorenzo Bon

Mistro Lorenzo Bon

Mistro Lorenzo Bon

Mistro Lorenzo Bon

Mistro Lorenzo Bon

Primo Settembre Lorenzo

Bon per intiero saldo

9 d:to Sig:r Gio: Maria

Morlaiter

17 d:to Morlaiter

21 d:to Morlaiter

28 d:to Morlaiter per

intiero saldo

$$
\begin{aligned}
& \text { Ce: N.o 30: } \\
& \text { Ce: N.o 15: } \\
& \text { Ce: N.o 15: } \\
& \text { Ce: N.o 15: } \\
& \text { Ce: N.o 10: }
\end{aligned}
$$

Ce: N.o 17: e.

Ce: n:o 15

Ce: n:o 15

Ce: n:o 10

Ce: n:o 32

Z 16

Z 660

Z 330

Z 330

Z 330

Z 220

Z 6: Z 380

Z 330

Z 330

Z 220

6 Z 474:-

Z 408:-

Z 198:

Z 66:

Z 132:-

$Z$

Z 220

Z 3850

Segue altre spese

Per una caseta di nogera

Per drapo per fodra della Medema B:a Z: D:mi 1

All'Intagliadore Mistro Andra

Per una croce fatura, e indoradura, come da Poliza

Z 21:-...10

Z 132:-
Più all' medemo Mistro à conto delle altre fature $\quad$ Z 98:-

All' Favro per conto (saldato) delle sue fature $\quad$ Z 132:-

Per il Crivello Z 8:-

Per piombo N 18 Z 9:-

All' Mistro che ha fodrato la Custodia, e Portella Z 9:-

Per due sachi Novi Z 5:-...10

Primo Settebre 1762 per saldato il conto di

legname, fature, e peatte à Mistro Lorenzo

Bon, come Polizza Z 521:-

per saldo di altra poliza saldata ogi Summa Z 956:-

à Mistro Giacomo per S. Maria

case per li Angiolli, per le Alle,

Custodia, caseta per la Custodia

Fodrata, e per il remenato con $\quad$ Z 50

Per arpesi di rame $\quad$ Z 70

All'Mistro Indoradore li sia hà contato a conto $\quad$ Z 220

Lasciati all'Sig.r Giamaria Morlaiter Zechini 24 (?) Z Z 528

Come apare dalla ricevuta per saldi delli

Mistri Indorador Favro, e Intagliadore

Per la Custodia

Z 10:-

Epistolario primo

Dok. 9

Per suplire ali Soldi oltrascriti sarano per l' Altarista L 2250: -

Spesa di Cassoni, Peate, et altro in Circa L 200

Per il scultore L 1350

Per la Cima del tabernacolo in Circa L 120:-

Per l' Adobbo, Capela

La Doradura in Circa $\quad$ L 600

Summa

L 4520

Per remesse (?)bliche

ad operarsi in Zara

L 990

Spese di Viaggio, Nolo, e

di sbarco

L 160:

$\begin{array}{ll}\text { Summa } & \text { L } 5680\end{array}$

Quando siano contati li Cechini quindici al signor

Morlaiter, come sono stati convenuti per conto d' un (?)

Nell' atto del saldo, li saranno calcolate Lire 80 di nuovo, quali non sono comprese

ne' fati contraenti

Non essendo calcolato, a differenza del (?)

il contra (?), li si doveranno contare

Lire L 250:- di più del sopra scritto suo saldo;

e saranno disposti Li Cechini quindeci, sono L 330: per suplimento di

altro impegno

Le Monache hanno Contato per Residuo cechini numero 116 sono L 2552

Z 8:- $\quad$ Per Spesa di Adobbo, et

imbarco hano dati cechini 40: L 880:-

Si Conteranno di (?) per Saldo L 1057:-

Z 100:- Del tutto(?) effetivi Cechini 112:- 
e sono L 2464:-

Causiale Begna L 650:-

Confesore il Sadricich (?)

Per Mano del Murgili L 2200

6317:-

Più effetivi in Valuta

88:-

L 6402

4680

Anci farano

L 1722

Mancando per Fratelli li soprascritti Contarenti, in tutto ò in parte,

Concordante senza dilazione, ritrovare (?) sopra le che si $\mathrm{pa}(?)$

per l' effetion, (?) e inspe(?) alcuna, che possa amettersi, ò differirsi.

Sarà eseguito il (?) impegno del

Consultor Ponte, e spedizione la piu solecità del (?)

e Consultor stesso etc.

Dovranno procurare di trovare modo, e mezzo

(?), per fare a Avogaria ali Morlaci (?) di G(?) ò lettera

Avogaresca

Declaratoria, ò ricorso al Collegio, ò informazone al Con-

siglio di Quarantia.

Havendo audienza da Sua Eccelenza Foscari, farne

a ricercarne direzione, e Consiglio,

con quale si fara perche delli (?)

del Signor Nassi.

Tengo in deposito Cechini numero 35

del Voivodich, de quali deve

servirsi per facilitare l'acomodamento del suo imbarazo del

Publico

al sollievo dello Pieggiosima del

Fratello Checo, à che si darà mano,

per l' effeto, facendo Pur(?), e procurare

al Signor Ferigo Medi(?) Raggionato.

Cechini 47: che mancano

45: adoperati

7: Nolo e spese di viaggio

18: (?), e ritorno

Cechini 117:

60: (?)

Cechini 177: Si Scoderano

Causidico Begna Cechini 3 :

Soderi(?) 4:

Margili

$10:$

Cechini 17:

Dok. 10

Pismo Giovannija Marije Morlaitera benediktinkama u Zadar

Adi(?) 18 Maggio 1762 Venezia(?)
Capitatto da me il Sio ${ }^{r}$ Bortolo suo Aggente con le racomandazioni di sollecitarmi per il compimento delle stattue per l'Altare delle Reverende Monache di Sant ${ }^{\mathrm{a}}$ Maria di Zara ed assieme rillevo della Riveri(ndissi)ma sua di V(ostra) S(ignoria) Ill(ustrissi)ma, chè sia stato datto ad intendere alle dette Reverende Monache, che iò avvendo fatto le stattue per loro avesse preso un arbitrio di vendere le stesse stattue con suplire con altre due, è che si faccesse di novo in luoco delle altre che fosse statte vendute, cosa mai pensata ne mai avverebbe potutto avver luoco, stante simili cose non seria da potersi fare chè da qualche Bricone; compatisco le Monache mentre esse non a la cognizione del mio carratere ma non si puo compatire quella sorte di gente che innventa simile cose, è ben comprendo che anche à Zara non vi sia carestia di Briconi lassiamo, a parte

Mistro Lorenzo sò, che va aprocurando il posibile, è per la disgrazia del pezzo di mezzo di fronte del Tabernacolo lassiato doppo alquanto lavoro in disparte, à caggione di disgrazia incontratta nel marmo, avvanzato che erra il lavoro qual lo necessito aquistar novo marmo ed a qestora sono liberato dalle segature lo prendera per mano, è avvanzato nel lavoro che serà lo consegnera à me cio possi avanzar li lavori de puttini è seraglia, che quest in fatti portera la maggior tardanza. Circa gli Angeli li ò dovuti lassiar qualche mese in disparte dal lavoro confidando à V.S. Ill. ${ }^{\text {ma }}$ di esser statto impegnato di modelare per far la Stattua del Beato Gregorio Barbarigo, è di questo lei ben vede che non mi potei essimere comme lei puol cappire mentre è commisione del Prencipe per quanto al darli compimento non andera disgiunti dall'altare e arivera a tempo senza alcun immaginabile ritardo

Li scrissi, che il Mang. ${ }^{\text {or }}$ mi avveva contatti sotto li 27 Aprile Cechini dieci è più sotto li 15 Maggio altri Cechini quindici. serva di regola a V(ostra) S(ignoria) Ill(ustrissi)ma e con tutta la pienezza di stima Riverendola resto à riccevuti commandi di

$\mathrm{V}$ (ostra) S(ignoria) Ill(ustrissi)ma

Vostro devotissimo osservatissimo Servitore Gio: Maria Morlaiter Scu(?)or

Epistolario primo

[Prijepis i transkripcija: Darka Bilić, Miroslav Granić, Bojan Goja, Radoslav Tomić]

Split, Državni arhiv

3.

Dokument o oltaru u katedrali sv. Tripuna u Kotoru

\section{Adì 31 luglio 1777 Venezia}

Dovendossi esequire il disegno dell' Altare del Venerabile per ilu Duomo di Cattaro giusto al disegno da me ideatto cioè l'Altare con il Tabernacolo, e due Angieli in atto d'addorazione il tutto di marmo fin di carrara costerà Zecchini N 330

Dovendosi poi esequire anco il pavione con sua corona ornata di seraffini e due angioletti che lo sostenta di marmo din di carrara e il stratto o sia panno di Brocadello rosso o 
sia Giallo di Tori con fiori doratti a mordente il tutto ridoto a perfesione costerà Zecchini N 200

Gregorio Morlaiter di Giovanni Maria

Biblioteca del Museo Correr di Venezia, Mss. P. D. C. 2377/ XXVIII

\section{Bilješke}

1

JULIJE BAJAMONTI, Nastavak povijesti sv. Dujma u kojemu se opisuje prijenos njegova tijela, nedavno proslavljen $u$ gradu, Venecija 1770., u: Julije Bajamonti, Zapisi o gradu Splitu, Split, 1975., 252. Bajamonti je zabilježio da je oltar izradio "gospodin Morlaiter, izvrsni kipar«.

2

GIANNANTONIO MOSCHINI, Della letteratura veneziana del secolo XVIII fino a'nostri giorni, III, Venezia: Stamperia Palese, 1806., 100: altre opere di lui esistono per le città, che componevano la Veneta repubblica, (...) altre farne dovette per la repubblica di Ragusi.

3

IVAN KUKULJEVIĆ SAKCINSKI, Slovnik umjetnikah jugoslavenskih I, Zagreb 1860., 318. Kukuljević je donio podatke o Morlaiterovim djelima u Dubrovniku i Zadru: »Morlaiter Ivan Maria, vajar mletački, rodjen g. 1699. radio je njeke kipove za Dubrovnik, a g. 1759. do 1762. načinio za veliki oltar crkve sv. Marije kod monastira zadarskih koludjericah, dva velika angjela iz kararskoga mramora, zatiem dvoju djetcu (puttini) i obtok ili zarub nad uložnicom oltarnoga svetohranišća. Polag ugovora načinjenoga s obskrbnikom crkve, knezom Josipom Antunom Fanfonjom, i polag namirah ovoga, primi Morlaiter za rečeno djelo sedamsto dukatah, dočim je njegov drug Lovro Bon, načinivši isto svetohranište i oltar dobio 2300 dukatah.« Ostaje nejasno je li dobro obaviješten Kukuljević za dubrovačku kiparevu djelatnost imao podatke iz arhiva i lokalnih kronika ili se koristio Moschinijevim djelom.

4

MONICA DE VINCENTI, Gian Maria Morlaiter e alcune sue opere giovanili in Stiria e in Dalmazia, u: Francesco Robba and the Venetian Sculpture of the Eighteenth Century, (ur.) Janez Höfler, Ljubljana, 2000., 197-207.

5

MIROSLAV VANINO, Isusovci i hrvatski narod, Zagreb 1987., 81. Franjo Rogačić je umro ubrzo nakon narudžbe oltara, 1733. godine. Pokopan je u grobnici u kapeli ispred oltara Marijina Prikazanja u hramu. Na njoj je natpis: D.O.M./FRANCISCUS ROGACCIUS/DE TEMPO HOC/ET COLLEGIO/PRAECLARE MERITUS/OBIIT A.D. MDCCXXXIII.

6

RADOSLAV TOMIĆ, Djela Bartolomea Litterinija u Dalmaciji, Peristil, 47 (2004.), 52-55.

7

Crtež glavnog oltara za svetište Madonna delle Laste u Trentu koji je izradio Giuseppe Pozzo gotovo je identičan arhitekturi oltara u Dubrovniku. Usp. Andrea e Giuseppe Pozzo, (a cura di Roberto
(Prema M. De Vincenti, Gian Maria Morlaiter e alcune sue opere giovanili in Stiria e in Dalmazia, u: Francesco Robba and the Venetian Sculpture of the Eighteenth Century, (ur.) Janez Höfler, Ljubljana 2000., 206.

Pancheri), Venezia 2012., tavola 5. Crtež se čuva u Milanu (Convento dei Carmelitani Scalzi).

8

RADOSLAV TOMIĆ, Giovanni Maria Morlaiter, u: Zagovori svetom Tripunu. Blago Kotorske biskupije (ur.) Radoslav Tomić, Zagreb, 2009., 260-261, kat. 111.

9

NIKO LUKOVIĆ, Prčanj, Kotor, 1937., 298; NIKO LUKOVIĆ, Bogorodičin hram na Prčanju, Prčanj, 1965., 53; CAMILLO SEMENZATO, La Scultura veneta del Seicento e del Settecento, Venecija, 1966., 136; ANTON RESS, Giovanni Maria Morlaiter, München - Berlin, 1979., 6-7, 10, 30-31, 45-46; KRUNO PRIJATELJ, Barok u Dalmaciji, u: Anđela Horvat - Radmila Matejčić - Kruno Prijatelj, Barok u Hrvatskoj, Zagreb, 1982., 755, 764; KRUNO PRIJATELJ, Likovni barok u Boki Kotorskoj, u: Dubrovnik: časopis za književnost, nauku i umjetnost, 4 (1993.) 226; RADOSLAV TOMIĆ, Barokni oltari i skulptura u Dalmaciji, Zagreb, 1995., 131, 137, 205; MASSIMO DE GRASSI, Barokna skulptura u Boki Kotorskoj, Podgorica, 2001., 86; ŽELJKO BRGULJAN, Crkva Rođenja Blažene Djevice Marije u Prčanju, Zagreb, 2008., 24-25; RADOSLAV TOMIĆ (bilj. 8), 260-261; NIKO LUKOVIĆ, Prčanj, Kotor, 2010., 69-70.

10

JULIJE BAJAMONTI (bilj. 1), 252.

11

JULIJE BAJAMONTI (bilj. 1), 252.

12

ARSEN DUPLANČIĆ, Preinake glavnog oltara splitske katedrale u XVII. stoljeću, u: Prilozi povijesti umjetnosti u Dalmaciji, 43 (2016.), 323-326.

13

Na srebru je utisnut mletački državni žig, lav sv. Marka, te kontrolni žig, ZP ljiljan G pubblico sazador Zuan Piero Grapiglia, koji se spominje od 1758. do 1802. godine.

14

LJUBO KARAMAN, Eseji i članci, Zagreb, 1939., 81-96; KRUNO PRIJATELJ, Barok u Splitu, Split, 1947., 44-46; O pozlaćenoj kruni, pastoralu i križu piše JULIJE BAJAMONTI (bilj. 1), 254. Današnja kruna je novija.

15

Na posrebrenim okvirima ne zamjećuju se žigovi. Kartuše i drugi dekorativi dodatci nisu posrebreni.

16 RUDOLF WITTKOWER, Art and Architecture in Italy 16001750, Harmondsworth, 1978.; ORESTE FERRARI - SERENITA 
PAPALDO, Le Sculture del Seicento a Roma, Roma, 1999.; RUDOLF WITTKOWER, Gian Lorenzo Bernini, Oxford, 1981.; ALESSANDRO ANGELINI, Baroque Sculpture in Rome, Milano, 2004.

\section{7}

IAN WARDROPPER, Sketching on Paper and in Clay. Bernini's Use of Preparatory Drawing and Models, u: Bernini: Sculpting in Clay, (ur.) C. D. Dickerson III - Anthony Sigel - Ian Wardropper, exhibition catalogue, Metropolitan Museum of Art, New York, 2012., 27., sl. 24.

18

BRUNO COGO, Antonio Corradini scultore veneziano, Este, 1996., 279-290; ANDREA BACCHI, La scultura a Venezia da Sansovino a Canova, Torino, 2000., 728, f. 354.

19

RADOSLAV TOMIĆ, Skulptura II. Od XVI. do XX. stoljeća, Zadar: Zadarska nadbiskupija, 2008., 90-97; BOJAN GOJA, Contributo per l'altare maggiore di San Simeone a Zara: Baldassare Longhena, Francesco Cavrioli e 'mistro' Lunardo, u: Arte Veneta, 68 (2011.), 250-257.

20

Povijest, tipologija i stilske preobrazbe oltara s kipovima anđela ili svetaca koji nose sarkofag sa svečevim moćima ili stoje uz njega u mletačkoj umjetnosti samo su dijelom istraženi. Usp. PAOLA ROSSI, Gli angeli reggenti l'urna sepolcrale, un motivo ricorrente nella scultura barocca: modeli veneti, u: Barocco in Italia. $\mathrm{Ba}$ rocco in Boemia: uomini, idee e forme d'arte a confronto (ur.) S. Gracciotti - J. Kresalkova, Il Calamo, Roma, 2003; RADOSLAV TOMIĆ (bilj. 19), 90-97.

\section{1}

GIULIO LORENZETTI, D’un gruppo di bozzetti di Giovanni Maria Morlaiter, u: Dedalo, IX (1931.), 1006-1012; GIULIO LORENZETTI, Modelli e bozzetti di terracota e di terracruda di Giovanni Maria Morlaiter, u: Rivista di Venezia, XIV/5 (1935.), 226; MONICA DE VINCENTI, Nuovi contributi per il catalogo di Giovanni Maria Morlaiter, u: Saggi e memorie di Storia dell'arte, 23 (1999.), 35-40; PAOLA ROSSI, Giambattista Tiepolo e la scultura del suo tempo, u: Giambattista Tiepolo nel terzo centenario della nascita, (ur.) Lionello Puppi, vol. 1, Venezia, 1998., 171-176.

\section{2}

RADOSLAV TOMIĆ, Oltar Giovannija Marije Morlaitera u benediktinskoj crkvi sv. Marije u Zadru, u: Prilozi povijesti umjetnosti u Dalmaciji, 31 (1991.), 317-331; ISTI, Zadar: the Center of Venetian Sculpture in Dalmatia in the Seventeenth and Eighteenth centuries, u: Francesco Robba and the Venetian Sculpture of the Eighteenth Century (ur.) Janez Höfler, Ljubljana, 2000., 213-215; ISTI (bilj. 19), 46, 176-180.

\section{3}

ANTON RESS, Giovanni Maria Morlaiter, Berlin, 1979., 7-8.

24

RADOSLAV TOMIĆ (bilj. 19), 166-168.

25

MONICA DE VINCENTI (bilj. 4), 203-205; RADOSLAV TOMIĆ (bilj. 19), 180-184; MONICA DE VINCENTI, Storia del »fondo di bottega« di Giovanni Maria Morlaiter nel Museo del Settecento Veneziano di Ca'Rezzonico, u: Bulletino dei Musei Civici Veneziani, III serie, 6 (2011.), 26, kat. 38-39, 44, f. 38-39, 30-31, kat. 61,50 , f. 61 . Dimenzije modela u terakoti su: $16,7 \times 13 \times 7 \mathrm{~cm}$.

26

ANDREA BACCHI, The Role of Terracotta Models in Bernini's Workshop, u: Bernini: Sculpting in Clay, (ur.) C. D. Dickerson
III - Anthony Sigel - Ian Wardropper, exhibition catalogue, Metropolitan Museum of Art, New York, 2012., 47-61.

27

MONICA DE VINCENTI (bilj. 4), 204-205., f. 11-12; RADOSLAV TOMIĆ (bilj. 19), 47-48, 180-184; MONICA DE VINCENTI (bilj. 21), 30-31, 50, f. 61.

28

LINO MORETTI, Notizie e appunti su G. B. Piazzetta, alcuni piazzeteschi e G. B. Tiepolo, u: Atti dell'Istituto Veneto di Scienze, Lettere ed arti, CXLIII (1984-1985), 387; MONICA DE VINCENTI (bilj. 21), 42-43.

29 RADOSLAV TOMIĆ (bilj. 19), 22-24, 90-97. O oltaru sv. Jeronima usp. BOJAN GOJA, Oltar sv. Jeronima u crkvi Sv. Šime u Zadru i radionica Bettamelli, u: Ars Adriatica, 2 (2012.), 203-216.

30

MASSIMO DE GRASSI, Sculture venete del sei e settecento: i busti già al castello di Duino e il monumento Colloredo, u: Arte in Friuli arte a Trieste, 18-19 (1999.), 126-134; MONICA DE VINCENTI (bilj. 21), 48-49.

31 MONICA DE VINCENTI (bilj. 4), 204-206. O oltaru ne postoje nikakvi podaci ili tragovi da je bio podignut.

32

IVAN KUKULJEVIĆ SAKCINSKI (bilj. 3), 318; IVES ČAČE, Dva barokna altarista u zadarskom području, Radovi Filozofskog fakulteta u Zadru, Razdio povijesnih znanosti, g. 25, sv. 25 /12/ (1986.), 161-170; RADOSLAV TOMIĆ (bilj. 21), 127-131.

33

ANTON TOMIĆ, Crkva sv. Eustahija u Dobroti - hram pomoraca, Godišnjak Pomorskog muzeja u Kotoru, XXVII-XXVII (1979-1980.), 94-95.

34 MASSIMO DE GRASSI (bilj. 9), 20-21, 87-89; RADOSLAV TOMIĆ, Gregorio Morlaiter, u: Zagovori svetom Tripunu. Blago Kotorske biskupije (ur.) Radoslav Tomić, Zagreb, 2009., 277-278. kat. 140. Kip Gospe od Ružarija visok je $120 \mathrm{~cm}$.

35

MONICA DE VINCENTI (bilj. 21), 61, 63-64, 70, f. 57-58.

36

JOŠKO KOVAČIĆ, Gradnja župne crkve u Dolu i drugi tamošnji spomenici, u: Bračka crkva, 1/46 (2001.), 29-30; ISTI, Iz stare knjige dolskih bratovština, u: Bračka crkva, 1/48 (2002.), $40-41$.

37

JOSIP ANTE SOLDO, Župa Radobolja Katuni - Kreševo, Omiš, 1970., 21. Autor nažalost ne navodi dokumente kojima se koristio $\mathrm{u}$ radu. Kipovi su brodom stigli Cetinom uzvodno do lokalitetom Visuć gdje su ih preuzeli mještani i prenijeli do udaljene crkve.

38

CVITO FISKOVIĆ, Župna crkva u Blatu na Korčuli, u: Radovi Instituta za povijest umjetnosti, 16 (1992.), 87-88, 92-94.

39

Kipove anđela na oltaru sv. Vincenze Damir Tulić pripisao je Pietru Onighi. Vidi: DAMIR TULIĆ, Kamena skulptura i oltari 17. i 18. stoljeća u Porečko-pulskoj biskupiji, doktorski rad, Zagreb, 2012., 556, bilj. 1009. Taj je majstor u Dalmaciji poznat kao graditelj glavnog oltara u katedrali sv. Marka u Makarskoj (1786.), glavnog oltara u svetištu Gospe od Pojišana u Splitu 
(1790.) te oltara Duša od čistilišta u katedrali sv. Stošije u Zadru (1806.). No treba istražiti je li on istovremeno radio i kipove na oltarima ili ih je kupovao i postavljao na oltarnu arhitekturu. Važan podatak donijela je Elena Catra 2014. godine prema kojima je kipove mramornih anđela na zabatu, kip Nade na retablu i reljef Duša u čistilištu na predoltraniku na zadarskom oltaru izradio Bartolomeo Ferrari (Marostica /Vicenza/, 1770. - Venecija, 1844.) između 1802. i 1809. godine. Usp. ELENA CATRA, Dalla bottega all' Accademia: la famiglia degli scultori Ferrari a Venezia nell'Ottocento, tesi di dottorato, università Ca'Foscari, Venezia 2014., 58-60, 372. Vidi i: DAMIR TULIĆ, Bartolomeo Ferrari, kipovi Bogorodice s Djetetom i anđeli, 1804/5. godina (kat. jed. 125), u: PREDRAG MARKOVIĆ - IVAN MATEJČIĆ - DAMIR TULIĆ, Umjetnička baština istarske crkve, Kiparstvo 2, od 14. do 18. stoljeća, Pula, 2017., 382-384. Kip Ljubavi (Milosrđe, Caritas) na zadarskom oltaru nije Ferrarijevo djelo i on je blizak kipovima u Makarskoj i na Pojišanu u Splitu, pa je pitanje njihova autorstva za sada otvoreno, jednako kao i kipova u Blatu, Dolu i Katunima. Ako su kipovi radovi istoga majstora, on je djelima opremao različite radionice (Bruttapelle i Oniga) u Dalmaciji.

40

ANTON RESS (bilj. 9), f. 130-132. O Morlaiterovu utjecaju svjedoče i kipovi Bogorodice s Djetetom (Venecija, San Marcuola, oltar Gospe od Ružarija) i Djevičanstvo (Lendinara, Santuario della Beata Vergine del Pilastrello) Gaetana Susalija (1696.-1779.) koji na svoj način reciklira tipologiju svetačkih i alegorijskih likova našega majstora. Usp. MONICA DE VINCENTI, Gaetano Susali e Francesco Cadorin, scultori veneziani, u: Venezia Arti, 17/18 (2003/4.), 81, 83, f. 2 i 5.

\section{Summary}

\section{Radoslav Tomić}

\section{Giovanni Maria Morlaiter in Dalmatia}

This paper presents an analysis of the Dalmatian opus of sculptor Giovanni Maria Morlaiter (Venice, 1699-1781), which includes artworks ranging from the beginnings of his career to the old age. The earliest among them are those in St Ignatius' church in Dubrovnik, dated to 1729/30. These include the statues of Virginity and Humility at the altar of the Presentation of the Virgin Mary, as well as those of Faith and Charity at the altar of St Augustine, all commissioned by Franjo Rogačić (Rogacci) from Dubrovnik. Later on, in 1746, Morlaiter carved three stone angels for the altar of Our Lady of the Rosary in the parish church of the Birth of the Blessed Virgin Mary in Prčanj, Boka Kotorska. In the mid$18^{\text {th }}$ century, he was commissioned to sculpt the altar of St Doimo for the Split cathedral, which is his most ambitious artwork in Dalmatia, completed in 1767. As noted by Julije
Bajamonti, the commissioners had acquired a superb design in Rome, according to which Morlaiter was to carve the altar. At the same time, between 1759 and 1762, he produced a tabernacle altar with marble angels for the Benedictine church of St Mary in Zadar, in cooperation with the altar maker Lorenzo Bon. In the same city, in 1764, he carved a tomb for the military engineer Giovanni Francesco Rossini, with a portrait bust, a statue of Saint Simon, and angels. Terracotta models for both artworks that Morlaiter produced in Zadar are preserved at Ca' Rezzonico in Venice. Documents also mention a design for the main altar at St Mary's church, and archival sources include an autograph letter that the sculptor sent to the Benedictine nuns in Zadar.

Keywords: Dalmatia, sculpture, $18^{\text {th }}$ century, Giovanni Maria Morlaiter, Gregorio Morlaiter 